DOE/NASA CONTRACTOR REPORT

DOE/NASA CR-150780

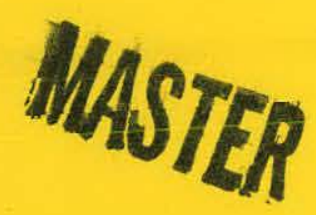

\title{
INSTALLATION PACKAGE IOR CONCENTRATING SOLAR COLLECTOR PANELS
}

Prepared from documents furnished by

Northrup, Inc.

302 Nichols Drive

Hutchins, TX 75141

Under Contract NAS8-32251 with

National Aeronautics and Space $\Lambda$ dministration

George C. Marshall Space Flight Center 35812

For the U. S. Department of Energy

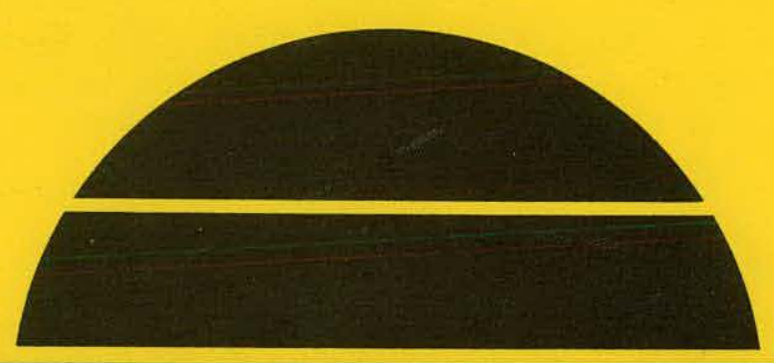

\section{U.S. Department of Energy}




\section{DISCLAIMER}

This report was prepared as an account of work sponsored by an agency of the United States Government. Neither the United States Government nor any agency Thereof, nor any of their employees, makes any warranty, express or implied, or assumes any legal liability or responsibility for the accuracy, completeness, or usefulness of any information, apparatus, product, or process disclosed, or represents that its use would not infringe privately owned rights. Reference herein to any specific commercial product, process, or service by trade name, trademark, manufacturer, or otherwise does not necessarily constitute or imply its endorsement, recommendation, or favoring by the United States Government or any agency thereof. The views and opinions of authors expressed herein do not necessarily state or reflect those of the United States Government or any agency thereof. 


\section{DISCLAIMER}

Portions of this document may be illegible in electronic image products. Images are produced from the best available original document. 
This report was prepared to document work sponsored by the United States Government. Nelther the United States nor 1ts agents the United States Department of Energy, the United States National Aeronautics and Space Adminfstration, nor any federal employees, nor any of their contractors, subcontractors or their employees, make any warranty, express or 1mplied, or assume any legal liabllity or responsibllity for the accuracy, completeness, or usefulness of any informat1on, apparatus, product or process disclosed, or represent that 1 ts use would not infringe privately owned rights. 


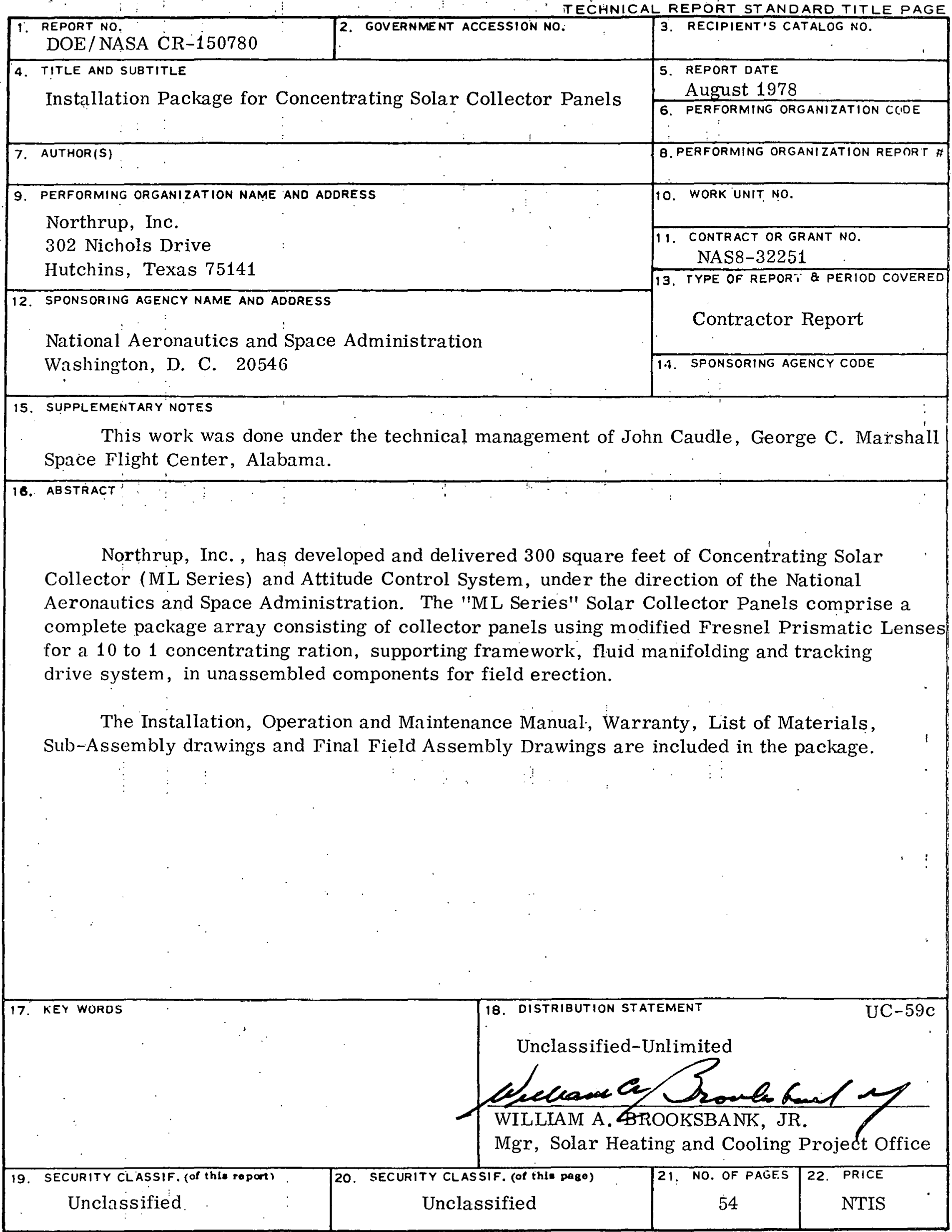




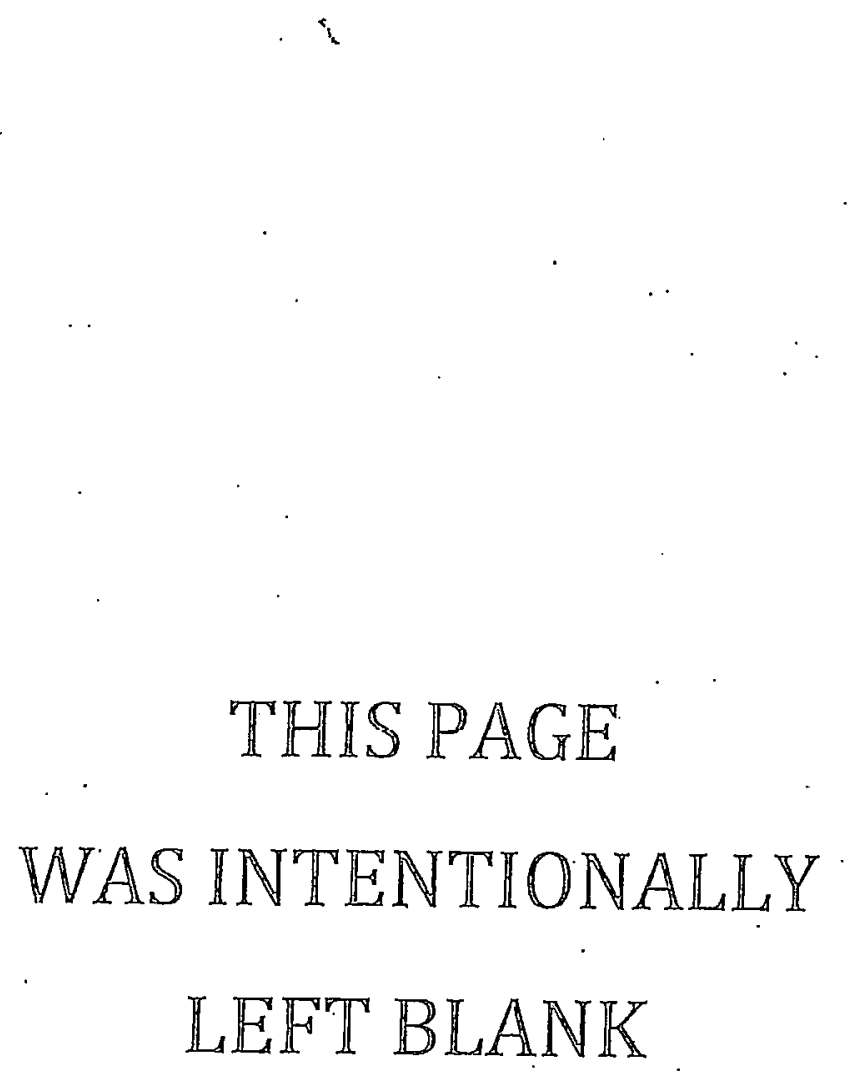


INSTTALLATION OPERATION \& MAINTENANCE MANUAL

FOR

NORTHRUP CONCENTRATING SOLAR COLLECTOR PANELS

WITH

INTEGRAL MANIFOLD-FRAME AND SUB-FRAMES

MF-NSC-P "ML" SERIES

MODEL NSC-01-0732

TABLE OF CONTENTS

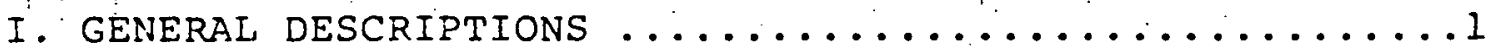

II. RECEIVING, UNPACKING, STORAGE, HANDLING \& HOISTING....2

III. INSTALIATION OF. FRAMING FOR COLLECTOR PANELS.......

IV. INSTALLATION OF COLLECTOR PANELS.............6

V. FIELD PIPING CONNECTIONS..................8

VI. PURGING, TESTING \& FILLING OF FLUID PIPING........9

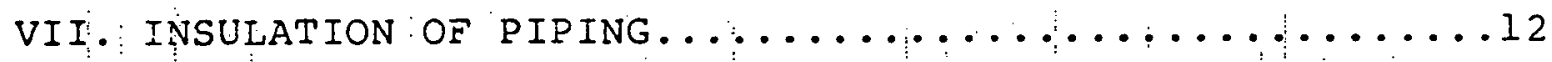

VIII. INSTALLATION OF TRACKING SYSTEM..............

IX. START-UP OF SYSTEM.....................

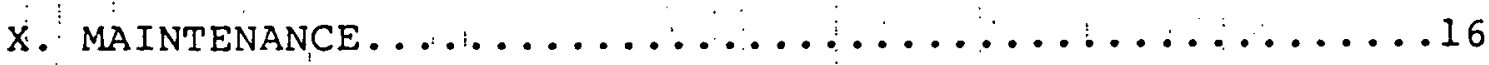

$\mathrm{XI}$. CODES \& REGULATIONS .....................

XII. WARRANTY $\ldots \ldots \ldots \ldots \ldots \ldots \ldots \ldots \ldots \ldots \ldots \ldots \ldots \ldots \ldots \ldots \ldots$

XIII. LIST OF MATERIALS

XIV. FINAL FIELD ASSEMBLY DRAWINGS

NOTICE MN ONLY

PORTIONS OF THIS REPORT ARE ILLEGIBLE. It

has boen renroduced from the best available, copy to permit the broadest possible avaib abilitity. 
I. GENERAL DESCRIPTION: "ML Series" Solar Collector Panels comprise a complete packaged array consisting of collector panels, supporting framework, fluid manifolding and tracking drive system, shipped from the factory in unassembled components for field erection as indicated on the drawings and described herein.

1. Model Numbers: The model number of the array with which these instructions are sent is as shown on the cover of the manual. Model number coding is explained as follows:

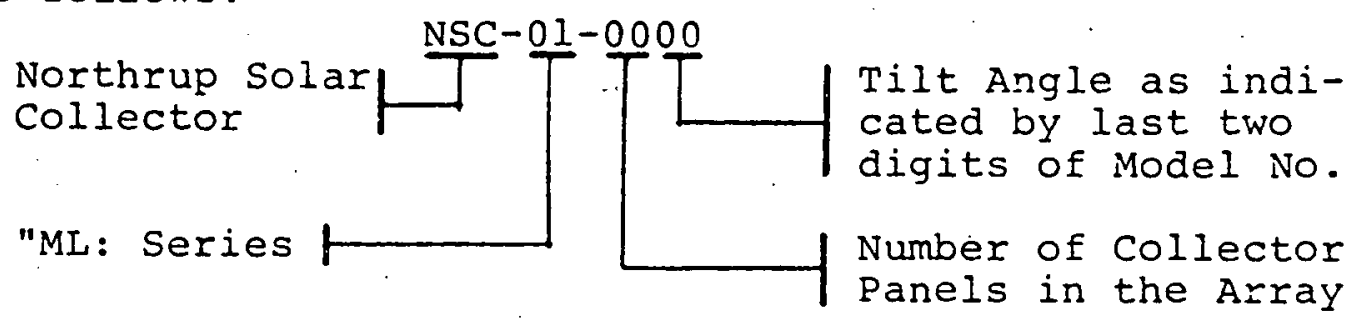

EXAMPLE:

Mode1. No. NSC-01-0732

"ML" Series

Seven Collector Panels

$32^{\circ} \mathrm{Tj} i t$ Angle

$7 \times 43=301$ Net. Sq. Ft. in the array

2. Drawings: Drawings and part numbers (at the back of the manual) are coded as follows:

a. Series 01-05-000: Final field assemblies showing location of components fully installed in place for operation.

b. Series 01-04-000: Field sub-assemblies showing assemblies to be accomplished in the field prior to installing in the final location shown on 01-05-000 drawings. They also list the number of components and parts required for that assembly.

c. Series 01-03-000: Shop final assemblies showing components as they are assembled at the factory and shipped.

d. All other number Series: Parts and miscellaneous accessories.

3. List of Materials: "List of Materials" (at the back of this manual) specify the number of each field subassembly, shop final assembly, parts and components 
required for the array model number. The total number of components, parts and accessories for the array model is the total of those listed for all field sub-. assemblies (Drawing Series 01-04-000) depicted on "List of Materials" plus the total of all other parts and components depicted on "List of Materials," not having part or drawing numbers in the 01-05-000 or 01-04-000 series. For convenience, the "List of Materials" also indicates the item number (or letter) for each assembly or part, and references in these instructions are made to these items. Refer to these item numbers (or letters) in "List of Materials" for the appropriate part of drawing number.

II. RECEIVING, UNPACKING, STORAGE, HANDLING AND HOISTING:

1. Receiving: Carefully unload and unpack parts and components as required to inspect and inventory all components, packages and crates. Report any shipping damage in detail to last carrier with copy of report sent to Northrup, Inc. Verify. shipment with "Iist of Materials" herein provided. Report any shortages in writing to Northrup, Inc.

2. Handling: Handle and unload all materials using fork lifts or other material handling equipment, ëmploying standard. recommended methods as to prevent damage to equipment. Utilize skids and pallets provided on components to properly lift and transport components.

3. Storing Components: Store in a safe location, in an orderly, sorted arrangement and as follows:

a. Open storage: The following components (except fastening devices for same,) may be stored in the open, properly secured, with access to limited personnel only:

Description

South wind Bracing

Upper North Wind Bracing

Inclined strut

mracking Control Box Mount

Idler Pulley Mount

Manifold Support

North wind strut

North Column

Lower North Wind Bracing

South Brace

South column Base Angles
Item

5

6

7

8

9

19 thru 32

37

A

B

C 
II.3.b. Receiving (cont'd)

b. Closed Storage: All other components and fastening devices and loose parts, not listed in "a" above, must be stored in covered dry location, until ready for installation.

\section{Hoisting Components:}

a. Framing Components (Items 7, 10, 11, 12, 13, 14 , 19 thru 32, 37, $A, C$, and E): May be hoisted with a crane and a cable sling around palleted bundle of members, or lifted by fork lift to the vicinity of assembly. After de-bundling components, all of these members can easily be handled by one or two persons.

b. Collector Panels (Item 4): May be hoisted by attaching to the eyebolts in each corner at top of panel with a four rope, or cable sling. Care must be exercised in attaching the sling, as to prevent sling members from bearing on lenses.

c. Other Components: All other components are of such size that will permit handling by one or two persons.

III. INSTALLATION OF FRAMING FOR COLLECTOR PANELS: Relative positions of the various components of the array are as depicted on Drawings 01-05-007, 01-05-122, and 01-05-129. sequence and method for installation is as follows:

1. Anchor Bolts and Column Bearing Points:

a. Layout all anchor bolts to dimensions given on "Bolt setting Plan," 01-05-123, allowing sufficient projections for washers and nuts above base angles. Orientation of array anchor bolts must be as indicated using "true north" and not "magnetic north." (Anchor bolts are not furnished by Northrup, Inc.)

b. Bolts must be positioned to maintain the tolerances of alignment given on "Bolt setting Plan." Tolerances for column bearing points can conveniently be maintained by proper field supplied shimming.

2. Sub-Assembly of Framing:

a. The following members which are spaced 10'-0" on center as shown on Drawing 01-05-007 and shown in Section "CC" of Drawing 01-05-122 are to be assembled as individual units prior to erection of framing: 
II.2.a.Installation (cont'd)

North Column (A)

Inclined Strut (7)

North Manifold Support (28) - (32)

South Manifold Support (19) - (23)

South Base Angle (D)

South Brace (C)

b. Assemble these units using the devices as listed below which are included in the bill of material of the field installation drawings for each member. At this time, tighten all of these bolts "finger tight."

\begin{tabular}{|c|c|c|c|c|c|}
\hline \multirow[b]{2}{*}{$\begin{array}{l}\text { Connection at } \\
\text { Members }\end{array}$} & \multicolumn{5}{|c|}{ Number Required } \\
\hline & $\begin{array}{l}\text { 桨" } \\
\text { Bolt }\end{array}$ & $\frac{1}{2}$ " Nut & $\begin{array}{l}\frac{1}{2} \text { Lock } \\
\text { Washer }\end{array}$ & $\begin{array}{l}\frac{1}{2} " \\
\text { Flat } \\
\text { Wash }\end{array}$ & $\begin{array}{l}\text { Bolt } \\
\text { Spacer }\end{array}$ \\
\hline $\begin{array}{l}(7),(A) \text { and } \\
\text { North Mani- } \\
\text { fold Support } \\
(28)-(32)\end{array}$ & 1 & 2 & 1 & - & $\begin{array}{l}\text { One } \\
\frac{1}{2} " \times 47 / 8 "\end{array}$ \\
\hline $\begin{array}{l}\text { (7), (D) and } \\
\text { South Manifolo } \\
\text { Support } \\
(19)-(23)\end{array}$ & 1 & 1 & 1 & 2 * & $\begin{array}{l}\text { One } \\
\frac{1}{2} " \times 5 "\end{array}$ \\
\hline $\begin{array}{l}\text { (C) and South } \\
\text { Manifold } \\
\text { Support } \\
\text { (19) - (23) }\end{array}$ & 1 & 1 & 1 & - & $\begin{array}{c}\text { One } \\
\frac{1}{2} " \times 5 \frac{1}{4}:\end{array}$ \\
\hline (C) and (D) & 1 & 1 & 1 & - & $\begin{array}{c}\text { One } \\
\frac{1}{2} " \times 53 / 8 "\end{array}$ \\
\hline
\end{tabular}

*Install one washer between each base angle and South manifold support. 
III.3. Installation (cont'd)

3. Erection of Framing:

a. Immediately prior to erection operations, remove the top covers from manifold supports (28) - (32), by removing fastening screws. Retain screws and covers for later installation... Prepare ends of copper manifolds and copper tees for flexible connections for brazing as specified hereinafter. Refer to Drawings 01-05-007 and 01-05-122.

b.: Beginning at the East end of the array, erect the first two sub-assemblies. of III, 2 above, and install manifold strut (14) and a North wind strut (37) on the North end between these assemblies, and manifold strut (10) on the South end between these assemblies. Join each end of each manifold strut to each manifold support with four $3 / 8$ " $\times 3 / 4 "$ bolts, nuts and lock washers, and each North wind strut with two $3 / 8$ " $\times 3 / 4$ " bolts, nuts and lock washers at each manifold support.

c. Install South wind bracing (5), upper North wind bracing ( 6 ) and lower North wind bracing (B) between these two East sub-assemblies as shown on assembly drawings for items (5), (6) and (B). Adjust turnbuckles of wind bracing to: position these two subassemblies in an approximate square and plumb position. Do not tighten lock nuts on turnbuckles.

d. Continue westward along the array and erect the remaining sub-assemblies of Paragraph III.2 in similar manner as the first two on the East as described in Paragraph III.3.a,b, and $c$ above, and with following additional instructions:

(1) Make sure that at each manifold support the proper size copper tee is used as listed and depicted on Drawing 01-05-007. (Tees are shipped as loose parts.)

(2) Install manifold struts in the sequence of item numbers depicted, with proper size copper manifold, all as shown and listed on Drawing 01-05-007. All manifold struts are physically marked (10) through (14).

(3) When installing manifold struts (10) - (14), install copper pipe manifolds into pipe tees, but do not braze joints until all framing and collector panels have been installed and finally adjusted as described hereinafter. 
III.3.d. (4) Installation (cont'd)

(4) Install wind bracing (5), (6) and (B) only in the bays as shown on Drawing 01-05-007.

e. Tighten all bolts securely, except the pivot bolt connecting North columns (A), inclined struts (7) and North manifold supports (23) - (32).

f. Adjust turnbuckles of South wind bracing (5) to square the angle made by the intersection of South manifold supports (19) $-(23)$ and manifold struts (10) - (14) within $+1 / 8$ " for the length of the South manifold support. Repeat this squaring operation for North manifold supports $! 28-(32)$ and North manifold struts (10) - (14), by adjusting turnbuckles of upper North wind bracing (6). Tighten all lock nuts on turnbuckles after these adjustments and wind bracing is snugged-up tight.

IV. INSTALLATION OF COLLECTOR PANELS (4):

1. Field Sub-Assembly of Collector Panels: Refer to Drawing 01-04-004, and identify North end of collector as. having the longer of the two end shafts. Before erecting collector panels, perform the following sub-assembly.

a. Install lens by inserting inside grooves on bottom of lenses into the flanges of lens guides, and sliding lens into position, making certain that lenses are parallel to lens guides both vertically and horizontally to prevent stresses and breakage of lens. Position lenses so that they are flush with lens guides on North end only and the predrilled holes in lenses are at the North end.

b. Install lens retainers 01-06-030 as shown, flush with North end of lenses and lens guides, using two No. $8 \times 5 / 8 "$ self-drilling, self-tapping screws with neoprene washers. Install two No. $6 \times \frac{1}{2}$ machine screws, nuts and washers through slotted holes in each lens retainer through predrilled holes in lenses as indicated.

c. Install pulley on North collector shaft by screwing angle brackets to end of collector panel as indicated.

2. Erection of Collector Panels:

Collector panels must be hoisted by use of four eye bolts as described in section II.4.b. The South shaft of collector panels must be inserted in the bearings of the South manifold supports (19) - (23) first. 
IV.2.a.Installation (cont'd)

a. It is recommended, that before collector panels are erected, the shafts of the panels and the aligning ball of the bearings be coated with "Never-Seez," manufactured by the Never-Seez Corporation, Broadview, IL 60155, per their recommendations: The aligning ball should be rotated at an angle to the shaft's axis while applying this lubricant to insure full coverage:

b. The South collector shafts must be inserted into bearings on the South manifold supports (19- (23) before the North shafts are inserted. Hoisting must be by use of the four eye bolts as described in Section II.4:b. For convenience, the aligning ball of the South bearing may be adjusted to position the bearing at the proper angle for landing the shaft into same.

c. If the collector height! to which the collector panel must be lifted is quite small, a jib pole or cradle frame with chain hoist could be used for hoisting, if collectors were not to be installed on roof of the structure.

d. When inserting North shaft irito bearing, pull the North manifold support (28) - (32) toward the North to allow clearance, and when positioned into bearing push the support South.

e. Allow the end of the south shaft to extend to face of South manifold support and the end of the North shaft to extend to face the North manifold support. When this is accomplished, the distance between faces of North and South manifold supports should be 11'-7" (139"), and then all set screws of bearings should be tightened securely.

f. Adjust the turnbuckles of lower North wind bracing (B) so that at any point along the North end of each collector panel, the distances between the end of collector panel and North manifold strut (10)-(14) is not in variance more than 1/8". After this, snugup turnbuckles and tighten lock nuts on turnbuckles. securely tighten pivot bolts mentioned in Paragraph III.3.e. above.

g. If collectors are to be left overnight or unattended for any period of time before tracking systenl: is installed, they must be temporarily held in place to prevent rotation and damage caused by wind. This may be accomplished by using a heavy nylon cord, 


\section{IV.2.g. Installations (cont'd) .}

making one loop around each collector panel pulley and securing cord tightly at each end of the array. Collector panels should be positioned with the lenses facing down for their protection and to prevent premature energy collection.

h. Install four manifold end closure plates to the manifold supports, located as shown on Drawing 01-05-007, using four screws in each plate. Refer to field sub-assemblies for items $(E),(F)$ and $(G)$. $(E)$ and $(F)$ plates are for the inlet and outlet to the array and have a hole for these pipes. (G) plates, (two required) are blank plates to cover opening in manifold supports. Install all these plates with weatherstripping adjacent to manifold supports.

i. Install idler pulley mounts (9) in accordance with drawing 0104-009 (one on extreme east and one on estreme west north manifold supports). Before installing mounts, it is recommended that the shaft be inserted in bearing with locking collars and pulley be slipped on the shaft to aid in aligning the pulleys parallel and to collector panel pulleys. Install flange stiffners as indicated. Adjust shafts and pulleys to align with collector pulleys and tighten locking collars, collar set screws and pulley set screws.

V. FIELD PIPING CONNECTIONS: Do not connect or braze any piping connections until the frame work and collector paniels have been installed and adjusted as described above. All piping joints within the array and immediately adjacent to the array must be made either by brazing or by pipe threaded connections to withstand a maximum temperature of $6000 \mathrm{~F}$.

1. Brazing: Brazing should be by trained and qualified persons using proper cleaning and heating methods recommended by manufactures of the brazing to prevent flux from oxidizing copper.

2. Pipe Threaded Joints: It is recommended that a teflon tape "pipe thread dope" be used on pipe threads, which will withstand the above temperatures.

3. Connections Required, Internal to the Array: Refer to Drawings 0104-004 and 01-05-122. Perform the following connections, making all brazed connections prior to threaded connections and un-assemble swivels before brazing bleeder connections:

a. In each North and South manifold support (28)-(32), braze the tee connection fo copper manifolds with the tee position as shown.

b. In each North manifold support (28)-(32) connect a flexible swivel connection which has a $l^{\prime \prime} \times \frac{1}{4}$ " tube connection for bleeder valve) Part \#01-09-029, to the collector panel outlet and to the tee connection of copper manifold with the swivel end on collector panel. Also, in each North manifold support, insert bleeder valve assembly, No. 01-03-060, through the grommetted hole in manifold support and braze bleeder valve to the $\frac{3}{4}$ " tube on swivel. 
V.3.c.Field Piping Connections (cont'd)

c. In each South manifold support (19) - (28), connect a flexible swivel connection \#01-09-130 (without bleeder valve tube) the same as for North manifold supports.

d. Braze a 3/4" plug into the unused tee connection of northwest and southeast manifold support as shown on manifold end closure drawing (G).

e. At the fluid outlet (F), braze the assembly to the tee connection in manifold support and install automatic air eliminator as shown on drawing for this item. Air eliminator must be positioned vertically.

f. At the inlet (E), braze the assembly to tee connection in manifold support and install pressure relief valve as shown for item (E). Pressure relief valve must be installed vertically.

4. Inlet and Outlet Connection to the Array

a. See Section VI "Purging and Testing, etc" prior to making final inlet and outlet connections.

b. Braze field system piping to inlet (F) and outlet (G) assemblies as shown for these assemblies.

c. At the inlet and outlet connections, flexible connections must be provided to allow expansion of manifold piping at the rate of $0.1^{\prime \prime}$ for each $10^{\prime}-0^{\prime \prime}$ system piping and is not furnished by the manuffacturer. See Application Manual.

VI. PURGING, TESTING \& FILLING OF FLUID PIPING:

1. Purging: The array should be thoroughly flushed either before or after connection to the system piping to remore debris that may have accumulated in the piping system. It is recommended this be done prior to connection to system piping as follows:

a. Leave outlet open to atmosphere and connect city water to inlet.

b. Flush water up through array at the rate of:2.0 GPM for each collector panel for about 15 minutes. While doing this, slowly rotate each collector panel three complete.: revolutions in each direction. Observe swivels for leaks. 
vI.1.c. Purging, etc. (cont'd)

c. Cap outlet temporarily, and leave city water pressure on system. At each North manifold support (28)-(32) open bleeder valve (by depressing the valve core) and allow water to flow through each valve for two minutes. Do the same with manual valve on automatic air eliminator valve and pressure relief valve.

d. Leave cap on outlet for pressure testing system later.

2. Pressure Testing and Drain Down:

a. Remove city water connection. Install a hydraulic pressure gauge on inlet of array having a range of 150 PSI.

b. Install a hydraulic (hand operated) pump to inlet down stream from gauge. Pump must have a check valve and a gate at discharge with check valve between pump and gate valve. Connect city water to inlet of pump.

c. Pump water into array, making sure array is filled with water by opening bleeder valves, automatic vent valve and pressure relief valves, and rotating collectors as in purging above.

d. Increase pressure to 120 PSI, close gate valve at pump and prove system tight by maintaining this pressure for 24 hours without loss in pressure. During this test period, each collector panel should be rotated three revolutions in each direction at end of each eight-hour interval.

e. When rotating collector panels, the nylon rope previously installed should be loosen and then re-lightened after rotation ".

f. Prior to releasing pressure after proving system tight, gradually increase pressure until pressure relief valve opens. Check pressure guage and note that this pressure should be 125 PSI \pm 3 PSI. Decrease pressure slowly and allow pressurē relief valve to close of its own accord to prove valve works properly.

\section{Drain Down after Testing:}

a. Remove hydraulic pressure guage, hydraulic pump and cap on outlet and begin to drain down of system. Allow array to drain down by gravity flow. Rotate each collector by hand three times. start at outlet end of array and work towards in-. let end. Repeat this step until no more solution flows from outlet pipe. It is advised that a rubber hose be attached to inlet pipe to carry solution away to appropriate site drains. Should 
VI.3.a. Purging, etc. (cont'd)

the array be left unconnected from the system piping for an extended period of time, it is recommended that inlet and outlet of the array be temporarily. capped to prevent further contamination.

4. Final Hook-Up and Filling of system:

a. System piping should be purged, flushed and free of foreign material and debris prior to connecting. to the array, by standard mathods applicable to the system.

b. If the array is to be protected from freezing, the system should have provisions for adding anti-freeze solution. Approximate percentages for industrial grade etheylene glycol for freezing protection is given in the table below. If other types of antifreeze solutions are used, they should be used per manufacturer's recommendations and assure that they are compatible with " $O$ " rings and valves seats in system. See Application Manual for volume of system and anti-freeze limitations. In mild climates, not subject to frequent freezing, fluid may be circulated during non-solar hours, by means of proper temperature sensing and controls.

c. Connect system piping per Paragraph V.4. Add proper amount of anti-freeze and fill system through water make-up system... Bleed valves and rotate collectors in similar manier as described for purging and testing above, to eliminate air in system.

FREEZING TEMPERATURE OF

10

0

$-12$

$-34$

$-62$
\&ETHYLENE GLYCOL 
VII. INSULATION OF PIPING:

1. All piping with the collector array, between the East faces of the East manifold supports and the West faces of West manifold supports, except those portions. within the top of each manifold support, (19)-(23) and (28)-(32), as indicated on Field Drawings 01-04-004 and 01-05-122, are factory insulated. After piping system has been proven tight as above, fill these top cavities with the pouring insulation supplied. Fill all voids around piping thoroughly by rodding with a wooden dowel. It is not necessary to compact this insulation but it is extremely important that all voids are filled. Each manifold support requires $0.30 \mathrm{Ft}^{3}$ or $0.6 \mathrm{lbs}$ of insulation. Amount listed in "List of Materials" allows wastage over this amount.

VIII. INSTALLATION OF TRACKING SYSTEM:

The following instructions described methods of installing tracking system and cable arrangement. They do not include adjustments in system or start-up procedures described hereinafter. It is recommended that final installation of the cable drive assembly (H) and sensor attachment (J) not be made until the system is fully connected and fluid is circulating in the array.

1. Tracking Control Box (I): This unit is shipped completely assembled as shown on Drawing 01-03-069 as one unit. It is also fitted with sufficient cable to extend to next bay on East and West side of the control box, with a cable thimble and cable clamp on each end, ready to install turnbuckles.

2. Control Box Mount Assembly (8): Remove screws from control box cover and remove from control box. Install East and West control box mounts and control box with accessories and fasteners as indicated on Drawing 01-04-008. Locate this assembly in the array as indicated for Item (1) on Drawing 01-05-007.

3. Cable Drive Assembly (H): Refer to Drawing 01-04-072. Strike pins extending out bottom of power screw housing of control box should be at equal distance away from control box when shipped from factory. If not, loosen the set screw on motor sprocket, and rotate chain and large sprocket to equalize these distances. Tighten "set screw." Facing the tracking box and collector panel pulleys from the South (looking North) as viewed on Drawings 01-04-066 through 01-04-076, perform the following: 
VIII.3.a.Installation of Tracking (cont'd)

a. Remove temporary nylon rope securing the collector panels. Adjust all turnbuckles to 908 full extended length. Remove all pulley cable clamps at top of all collector pulleys.

b. Attach a turnbuckle through cable thimbles on each of the cables extending out of control box.

c. Thread west cable under adjacent West collector panel pulley and over its top in a clockwise rotation.

d. Thread East cable under adjacent East collector panel pulley and over its top in a counter clockwise rotation.

e. Let these two cables hang loose.

f. Unroll cable from the reel, laying it reasonably straight. Attach a cable thimble and clamp to one end: Attach the West turnbuckle to this end.

g. Extend cable to next West collector pulley, loop under the bottom and around pulley in clockwise direction. Continue westward to and around each collector pulley in same manner.

h. After looping around extreme West collector pulley, loop around west idler pulley in a counter clockwise rotation.

i. Extend cable back, eastward, (threading through two idler cable supports) (01-03-082) to bottom of East Idler pulley and around pulley in a counter clockwise direction.

j. Continue, cable westward under and around East collector pulley in a clockwise rotation and around all other collector pulleys in same manner until the collector pulley East of control box has been reached.

k. Loop end of cable through eye of East turnbuckle, stretch cable tight by hand, pulling end of cable eastward, and mark proper position for cable thimble.

1. Install a cable thimble and clamp at the marked position and attach to East turnbuckle. It is suggested that any surplus cable be allowed to remain until all adjustments have been made.

m. Tighten turnbuckles to remove slack in cable, but not tight enough that collector panels cannot be rotated slowly by hand, allowing cable to slip around pulleys. 
VIII.3.n. Installation of Tracking (cont'd)

n. Position all collector panels by hand to solat noon position (bottom of collector panel parallel to manifold struts $(10)-(14)$.

0. Install an idler cable support on north manifold support (29) and (33), with two self-drilling, self-tapping screws. Position these so that they hold cable in iine with cable at bottom of east and west idler pulleys.

p. Tighten turnbuckles so that idler cable has less than $\frac{1}{2}$ " SAG between supports.

q. Recheck position of collector panels to solar noon and install pulley cable clamps over the cable on each collector pulley, securing them tight.

4. Sensor Attchment Assembly (J): Install solar sensor on extreme East collector panel, centered on the East lens and install wiring of sensor as indicated to bottom of control box, as indicated, through grommeted hole and connect the black, orange, and blue wires to the corresponding color wires in the box with wire nuts. Tie-off any surplus wire with plastic wire ties (provided in box) to prevent interference with mechanism in control box. See tracking control box wiring diagram 01-02-016

5. Power Supply to Control Box: Provided a 120V, AC, 60Hz power supply to junction box on bottom of tracking control in accordance with National Electrical Code or local governing codes in force for the particular locality. This supply must have a ground continuity wire connected to grounding lug in junction box. Connect the hot leg of power supply to black wire in box and the neutral wire to the white wire in junction. If desired, a toggle disconnect switch may be installed in this junction box, to open the hot leg of power supply for convenience in servicing the tracking system. Full load current of tracking system is 0.50 amps or, 60 watts power consumption.

IX. START-UP OF SYSTEM:

1. Piping system must be fully connected as described herein before and flowing at proper rate (see Application Manual) before tracking system in energized.

2. It is preferable to perform alignment of collector panels from one to two hours before or after solar noon. After installing tracking system as described in Paragraph VIII, energize tracking motor and allow system drives collector panels westward for a few seconds and then is off for about 45 to 60 seconds. 


\section{IX.3. Start-Up of System (Cont'd)}

3. While system is tracking the sun, observe focal point (concentrated light beam) of the lens below solar sensor. Rotate solar sensor by loosening and tightening nut on positioning bracket so that focal point is centered on absorber tubes. Observe this condition for at least 15 minutes making adjustments if required to be certain it is focused and is tracking the sun properly.

4. In making adjustments of solar sensor as above, it should be remembered that if the focal point is East of the absorber tubes, a rotation of the sensor to move its top toward the East will move the focal point West toward the absorber tube, and visa versa.

5. After this panel is focused and tracking properly, adjust all other collector panels in the array (one at a time) by slightly decreasing tension on cable, loosening pulley cable clamp, rotating collector panel to proper focus (allowing cable to slip around pulley), and firmly retightening cable clamp and replacing tension on cable. 
The following routine maintenance should be performed:

1. Lenses (Cleaning of exterior)

a. Interval - on a "as required basis," per visual inspection, and especially after adverse weather conditions.

b. Cleaning procedure - clean lenses, when collectors are in a vertical position, by washing with a fine hose spray and washing with a mild, non-abrasive detergent, rinse and dry swith a soft (non-linting), dry cloth. When completely dry, coat exterior with a.0.258 solution of detergent (one ounce detergent to 13 quarts water) with a sponge or clean cloth which has been immersed in this solution and let dry by dust-free air. This will destaticize lens to help preclude dust attraction. Due to its chemical consistency, "Orvus $K$ " has been found to be a safe and suitable detergent for the above process. It may be purchased from Hampden Color \& Chemical Co., 126 Memorial Dr., Springflied, Mass. 01101, (413/732-2112). Since ordinary household detergents are changed chemically for improved household use, these should be used only after a thorough analysis has been made to insure no detrimental effects to acrylic lens.

\section{Lubrication}

a. Interval

(1) Every 90 days for control box chain. All other control box parts do not require lubrication.

(2) Bearings are the lubricated for life type and have no grease fittings and require no additional lubrication while in use.

b. Procedure

(1) Control box chain - lubricate chain with a lubricant that penetrates, demoisturizes, and prevents rust (i.e., Browning Chain Lube \#CII56).

\section{Cable Tension \& Condition}

a. Interval - check cable tension and condition every 30 days and after adverse weather.

b. Procedure: check to see that saq in idler cable does not exceed $\frac{1}{2} "$. Should sag exceed $\frac{1}{2}{ }^{\prime \prime}$, refer to 
installation instructions, Page 12, Paragraph VIII.1 for tensioning of cable. check cable for strand breakage (fraying) replace if wearing is evident.

4. Fasteners Check

a. Interval - every 60 days and after adverse weather.

b. Procedure - Using appropriate tools, check all nut and bolt combinations at frame bearing flanges. Check all pulley set screws, self-tapping screws and housing fasteners. All fasteners to be hand tight. Cautiondo not over tignten, stripping out of or breakage of fastener may occur.

\section{Exterior Finish}

a. Interval - check every six months.

b. Procedure - check for and locate areas of rust or rust scale. These areas should be treated with a $z$ inc rich paint similar to Z.R.C., applied and used according to manufacturer's spcifications. All galvanized metal products will in time oxidize leaving a white film on surface. This is not detrimental to the metal and does not require refinishing.

6. Valve Check

a. Interval - check bleeder valve, swivels, air vent, and pressure relief valve every 30 days.

b. Procedure

(1) Visually and physically check swivel for leakage. Replace entire assembly if leaking is present.

(2) Check pressure relief valve by lifting handle on unit and manually release pressure.

(3) Check bleeder valve manually by depressing valve core briefly.

(4) Air vent is to be checked visually, looking for fluid leakage at air vent cap (small) on top of unit. Should leakage be present, unscrew air vent cap and push in valve core allowing fluid to flow out. This will flush out valve seat. Next, pull out slightly on valve stem to dislodge any foreign matter. Repeat if necessary. If problem presists replace unit.

7. Leak Check.

a. Interval - every 30 days.

b. Procedure. - check all connections at manifolds, North and South, check inlet and outlet connections to arrays. 
X.7.b. Leak Check (cont'd)

Check collector housing for internal leakage by visual examination of collector's South end seams. Replace or repair items at leak location after shutting down and draining down system. If leakage is not readily accessible, consult factory for method of repair or replacement:

8. System Anchorage Check

a. Interval - every 60 days or after adverse weather conditions.

b. Procedure - visually and physically check anchorage devices for looseness, crack development and/or deformity at all anchorage points. Should a problem exist, consult facility's structural engineering representative.

XI. CODES AND REGULATIONS: Instructions and directions given here- . in are considered to be minimum standards. Requirements of $\sim$. any codes or laws in force, governing this type of installation, shall take precedence over these instructions should they conflict: however, approval to make these deviations must be approved by Northrup. Inc.

$\cdot-$

XII. WARRANTY: Warranty Certificates shipped with each order of collectors is limited warranty which states that the components of the Northrup Solar. System will:be. free from defects in material and workmanship for a period of 18 months from date of shipment from factory, or 12 months from installation date, "whichever occurs first.: 
IIST OF MATERIALS

$-19-$ 
IIST OF MATERIAIS

NORUHRUIP CONCENTRATING SOLAR

COIIDCTOR PANEIS, MF-NSC-P "ML" SERTES

MODEL NSC-01-0732
DATE: $\quad 1-16-76$

REV: $B$ 1-16-78

№. 01-05-076

PAGE 1 OF 2

\begin{tabular}{|c|c|c|c|}
\hline TTEM & QTY. & $\begin{array}{l}\text { DRAWING OR } \\
\text { PARI NUMBER } \\
\end{array}$ & DESCRIPTION \\
\hline 1 & 1 & 01.03 .069 & Tracking Control Box Assembly \\
\hline 4 & 7 & $01-04-004$ & Collector Panel Assembly \\
\hline 5 & 3 & $01-04-005$ & South Wind Bracing Assembly \\
\hline 6 & 3 & $01-04-006$ & Upper North wind Bracing Assembly \\
\hline 7 & 7 & $01-04-007$ & Inclined Strut Assembly \\
\hline 8 & 1 & $01-04-008$ & Tracking Control Box Mount Assembly \\
\hline 9 & 2 & $01-04-009$ & Idler Pulley Mount Assembly \\
\hline 10 & $2 \cdot$ & $01-04-010$ & Manifold Strut Assembly $3 / 4 "$ cu Manifold \\
\hline 11 & 2 & $01-04-011$ & Manifold Strut Assembly 3/4" cu Manifold \\
\hline 12 & 2 & $01-04-012$ & Manifold Strut Assembly I" cu Manifold \\
\hline 13 & 2 & $01-04-013$ & Manifold Strut Assembly I" cu Manifold \\
\hline 14 & 4 & $01-04-014$ & Manifold Strut Assembly I 1/4" cu Manifold \\
\hline 19 & 2 & $01-03-002$ & South Manifold Support 3/4" $\times 3 / 4$ " connection \\
\hline 20 & 1 & $01-03-003$ & South Manifold Support $1 " \times 3 / 4 "$ connection \\
\hline 21 & 1 & $01-03-004$ & South Manifold Support l" $\times 1$ " connection. \\
\hline 22 & 1 & $01-03-005$ & South Manifold Support 1 1/4" x 1" connection \\
\hline 23 & 2 & $01-03-006$ & South Manifold Support $11 / 4^{\prime \prime} \times 11 / 4$ " connection \\
\hline 28 & 2 & $01-03-023$ & North Manifold Support (w/Bleeder) $3 / 4 \times 3 / 4$ \\
\hline 29 & 1 & $01-03-024$ & North Marifold Support (w/Bleeder) $1 \times 3 / 4$ \\
\hline 30 & 1 & $01-03-025$ & North Manifold Support (w/Bleeder) $1 \times 1$ \\
\hline 31 & 1 & $01-03-026$ & North Manifold Support (w/Bleeder) $11 / 4 \times 1$ \\
\hline 32 & 2 & $01-03-027$ & North Manifold Support (w/Bleeder) $11 / 4 \times 11 / 4$ \\
\hline 37 & 6 & $01-04-024$ & North Wind Strut Assembly \\
\hline A & 7 & $01-03-032$ & North Column Assembly $32^{\circ}$ Tilt Angle \\
\hline
\end{tabular}


NORTHRUP CONCENTRATING SOLAR

COLLECTIOR PANELS, MF-NSC-P "ML" SERIES

REV: B 1-16-78

MODEL NSC-01-0.732

NO. 01-05-076

PAGE 2 OF 2

\begin{tabular}{|c|c|c|c|}
\hline ITEM & QTY. & $\begin{array}{l}\text { DRAWING OR } \\
\text { PARTL NUMBERR } \\
\end{array}$ & DESCRIPTION \\
\hline B & 3 & $01-04-035$ & Lower North Wind Bracing Assmb. $32^{\circ}$ Tilt Angle \\
\hline$c$ & $?$ & $01-04-044$ & South Brace Assembly $32^{\circ}$ Tilt Angle \\
\hline$\underline{\mathrm{D}}$ & 14 & $01-07-003$ & South Column Base Is \\
\hline$\underline{E}$ & $\unlhd$ & $01-04-057$ & Fluid Inlet Assembly 1 1/4" Manifold \\
\hline$\underline{F}$ & 1 & $01-04-062$ & Fluid Outlet Assembly 1 1/4": Manifold \\
\hline G & 2 & $01-04-065$ & Manifold End Closure 3/4" \\
\hline $\mathrm{H}$ & 1 & $01-04-072$ & Cable Drive Assemble 7 Collector Panels \\
\hline$I$ & $5 . \mathrm{ft}^{3}$ & $01-13-003$ & Ioose Fill Insulation (1 bag $-7.5 . \mathrm{ft}^{3}$ \\
\hline $\mathrm{J}$ & 1 & $01-04-077$ & Sensor Attachment Assembly \\
\hline
\end{tabular}


)

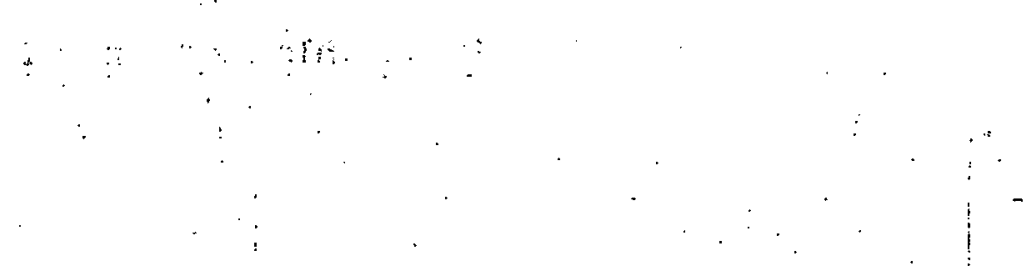

\section{- FINAL FIELD ASSEMBLY DRAWINGS}




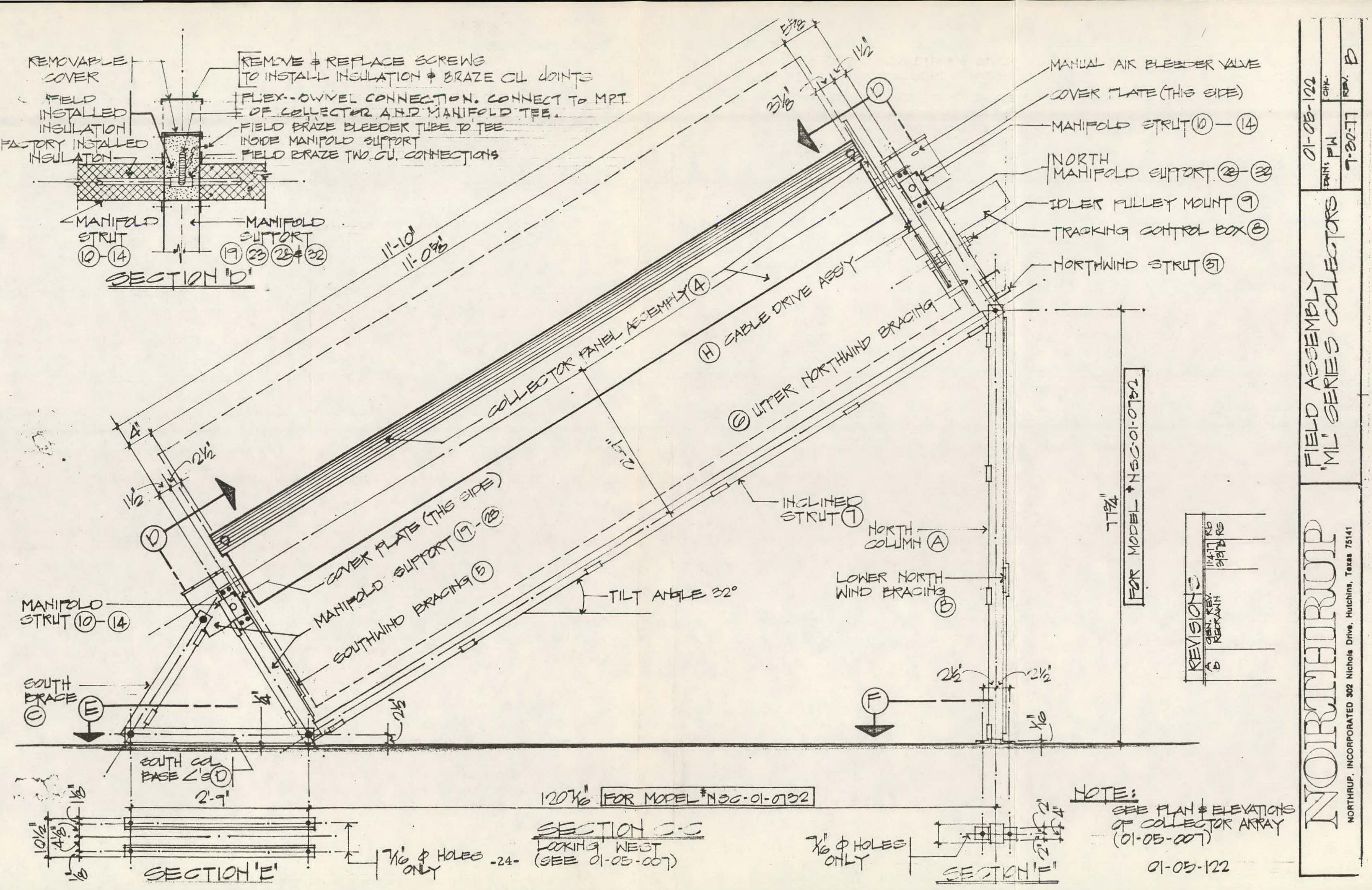




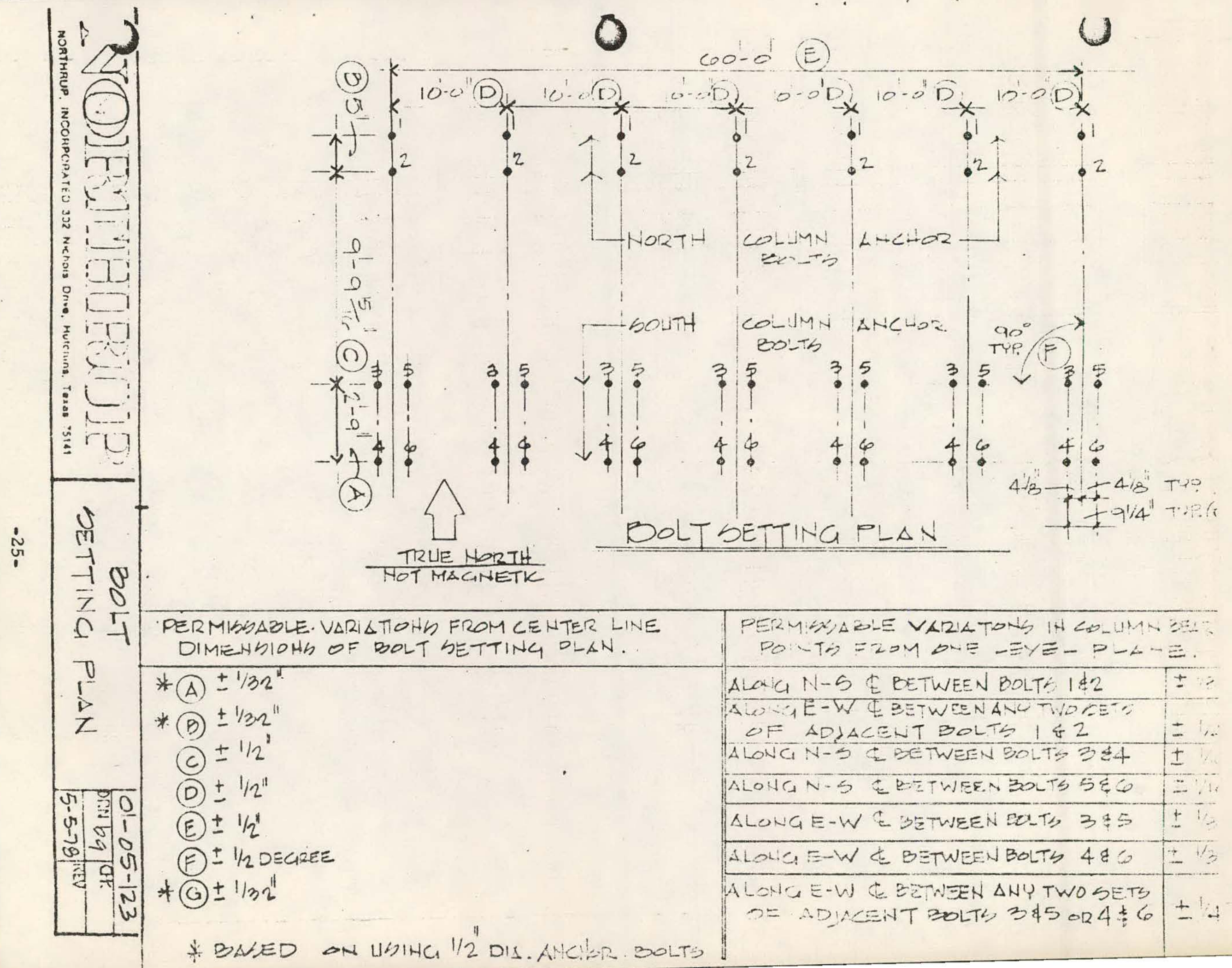


NOTE: 1, DEE PLAN Eे ELEVATIOHS DF COLLECTOR $\triangle R R A Y(01-0=-\infty 07)$

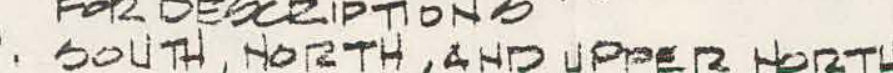
SOUTH, MORTH, AND UPAER HORTH OEIN (OI-OS-OOT) $\triangle H D(01-05-122)$

3. IOLERG PULLEU MOUNT, CONTROLLAX AND STER HOT SHOWN, SEE $(01-05-007)$ AIND $(01-05-12 i)$ FOR

4. JNE COLLECTOR PAHEL NOTSHOWN.

5. REF 01-05-007 DESCRIPTION CHART FOR. FIELD SUB-ASSEMBUT NUMBERS

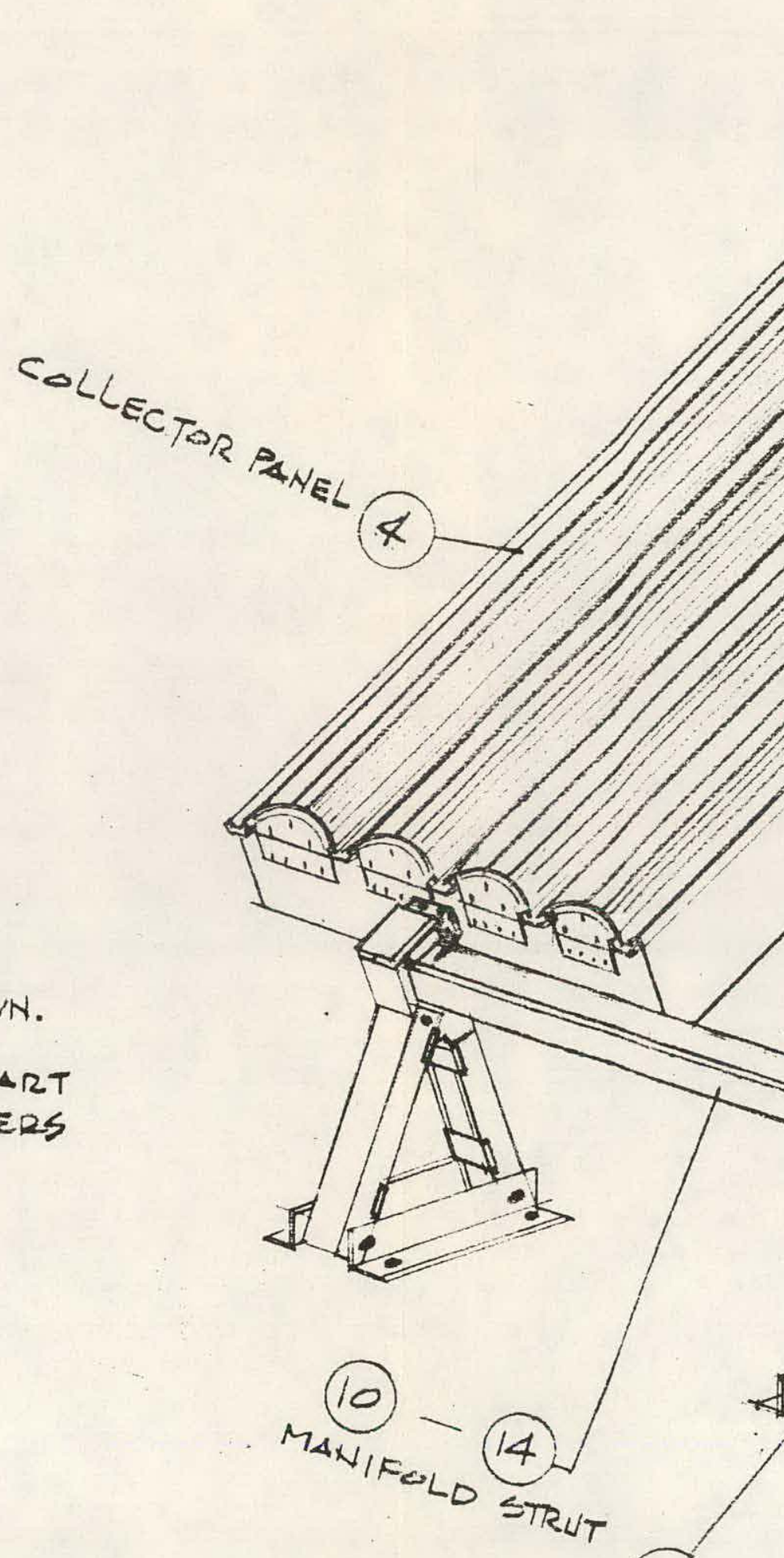

(c)

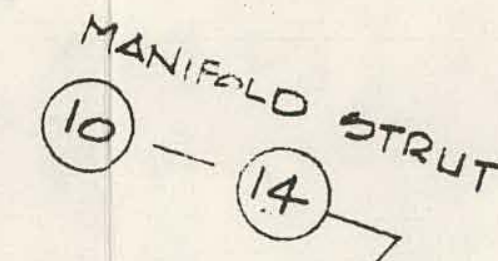

MANIFOLDORTH (28) $3{ }^{3 / P}$

SOUTH RECE 


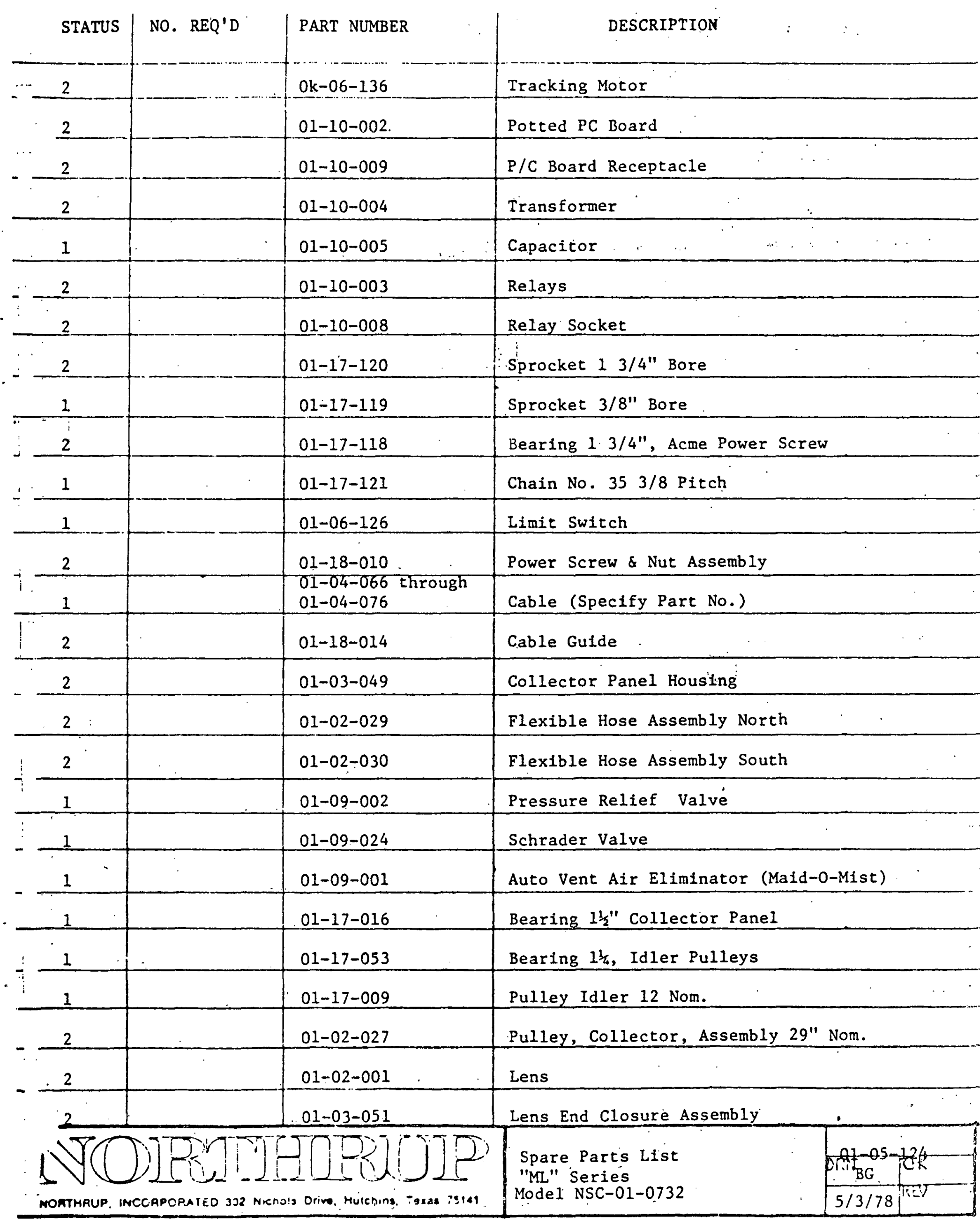




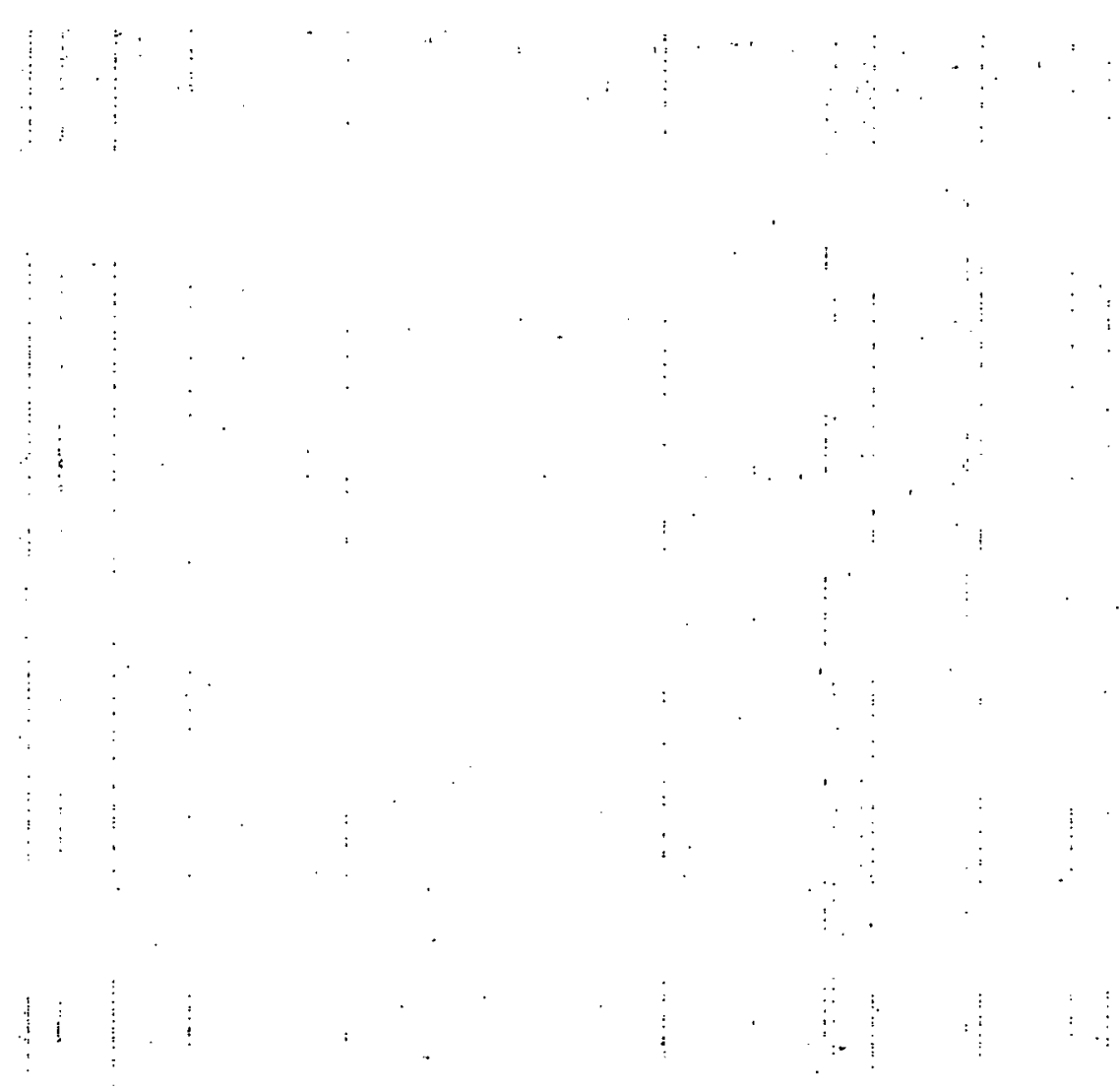

FIELD SUB-ASSEMBLY DRAWINGS 


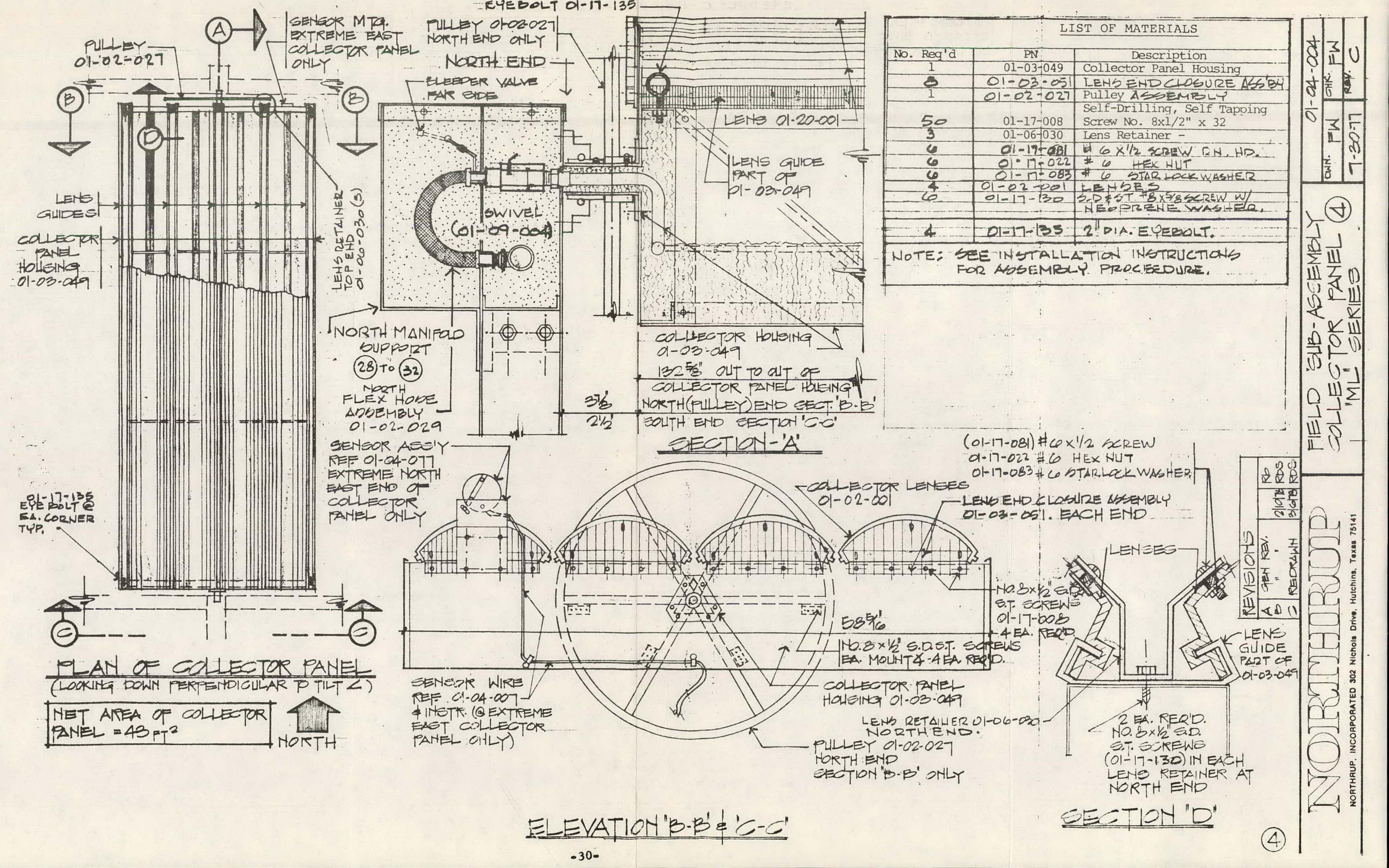



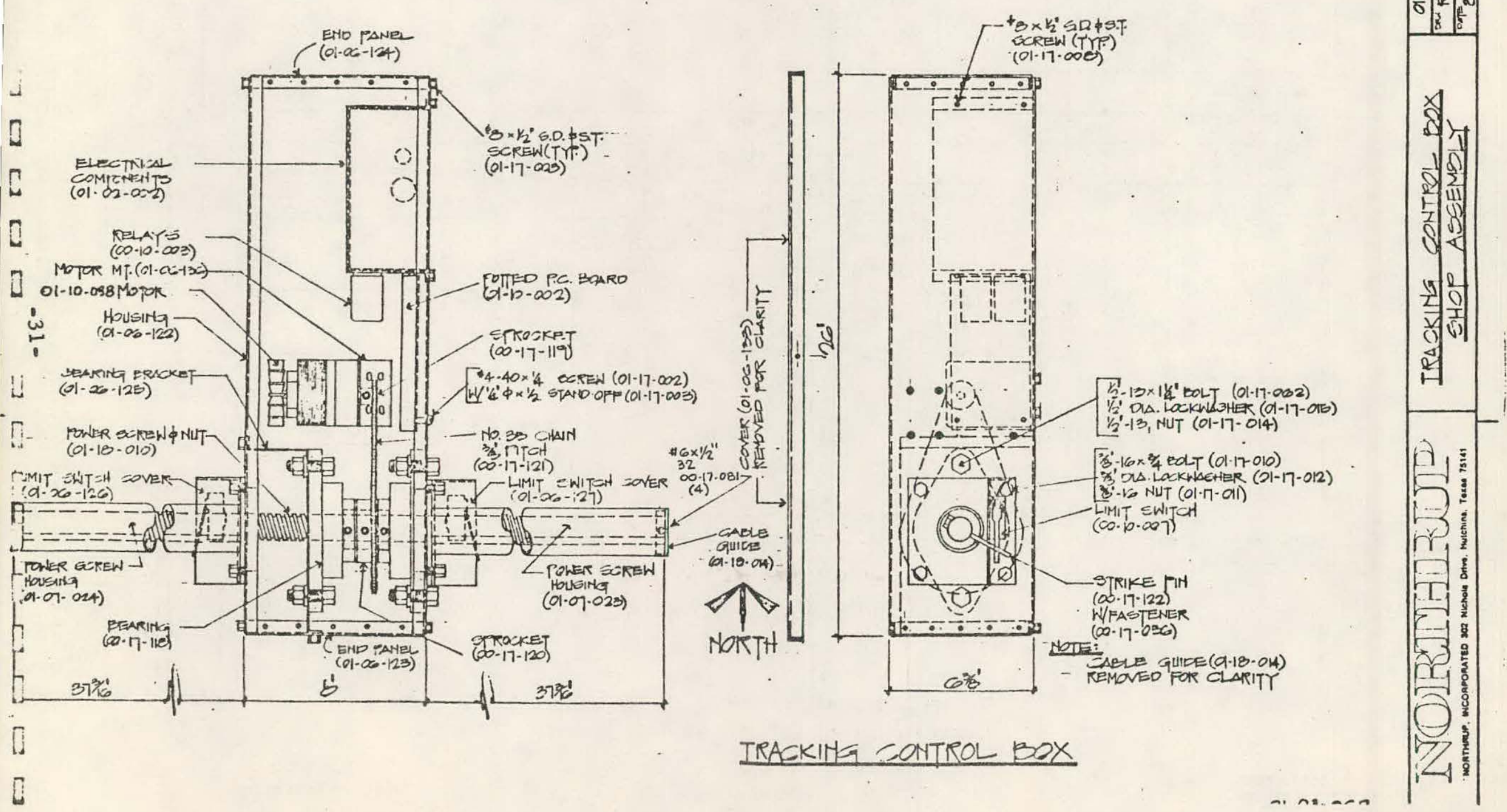
7

2VHIS/IABS
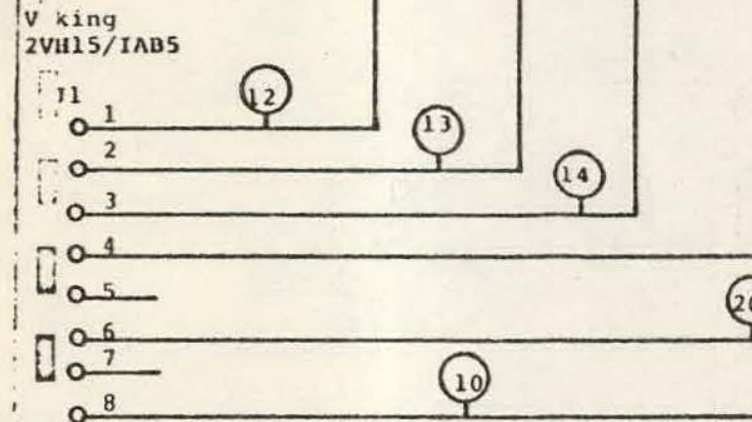

(2)

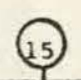

COM EAST (note ${ }^{2}$ ) WEST (note ${ }^{2}$ )

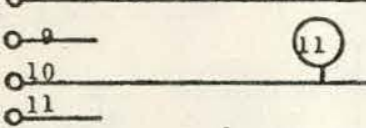

$$
010
$$
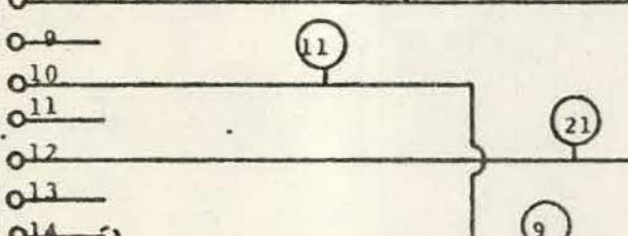

ols
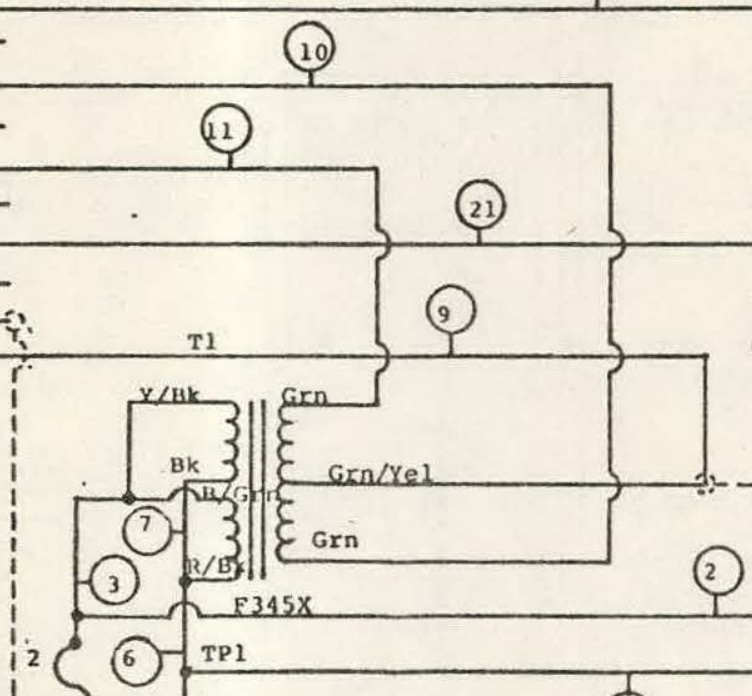

TP1

NOTE: (1) Wiring Diagram for (CW) Clockwise rotation of drive screw by travel of collectors. To wire for CCW reverse connection of motor's gray and yellow wires.

(2) rimit switch this end of control box.

EAST (note) WEST (note

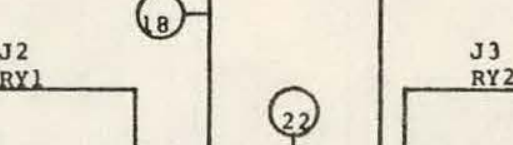

RY2
R 2

Gry (25)

MOTOR CAP 6 RE Optional Res

(3) Optional circuits shown dotted.

(4) observe (CW) or (CCW) rotation by facing output shaft of motor.

\begin{tabular}{|c|c|c|}
\hline & 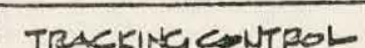 & $01-02-016$ \\
\hline 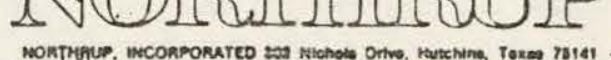 & $\begin{array}{l}\text { DOX } \\
\text { WIRING DIAGRAM }\end{array}$ & $\frac{D G}{10-2 G 7}$ \\
\hline
\end{tabular}



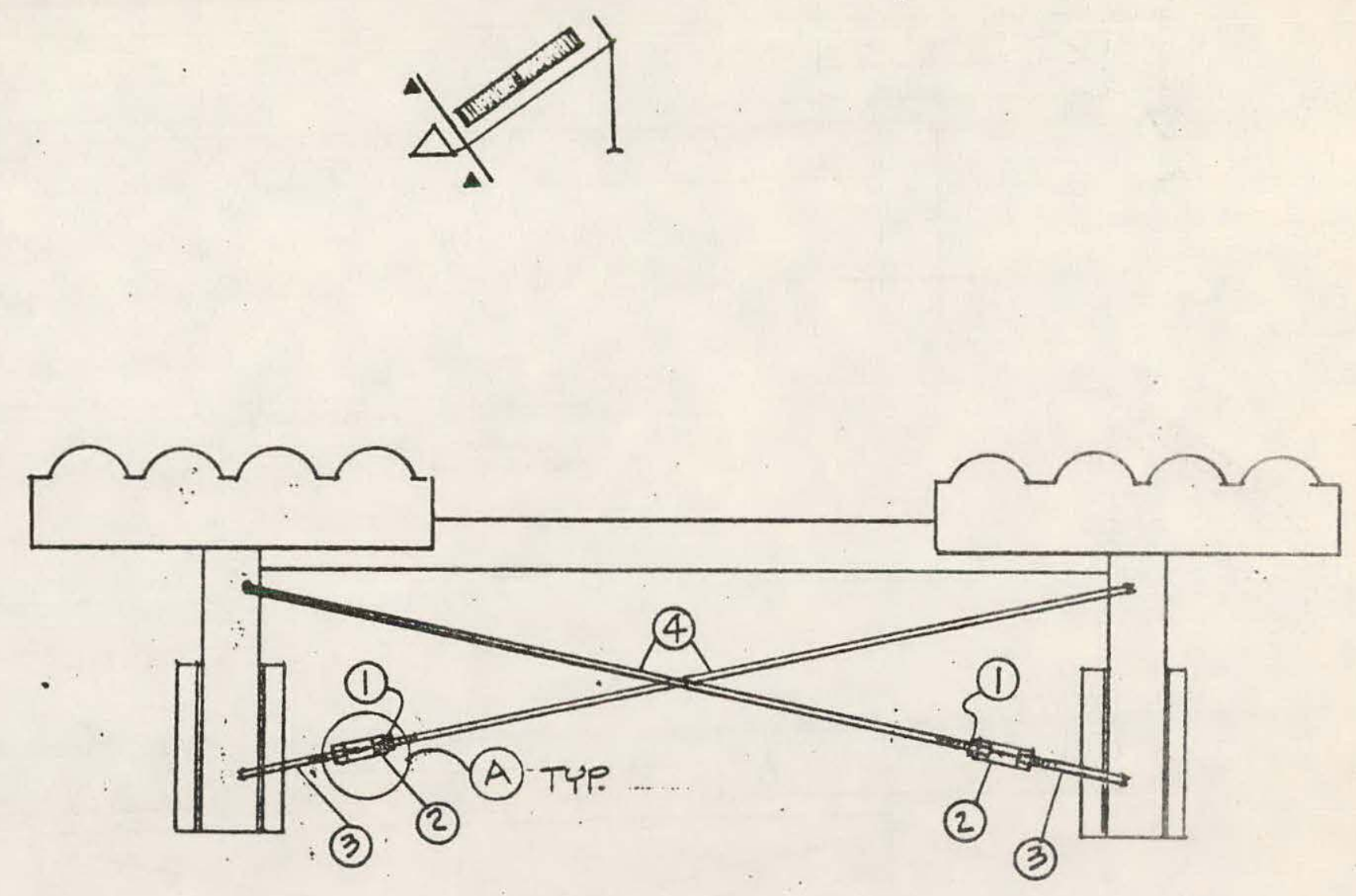

ELEYXTKA

(2)

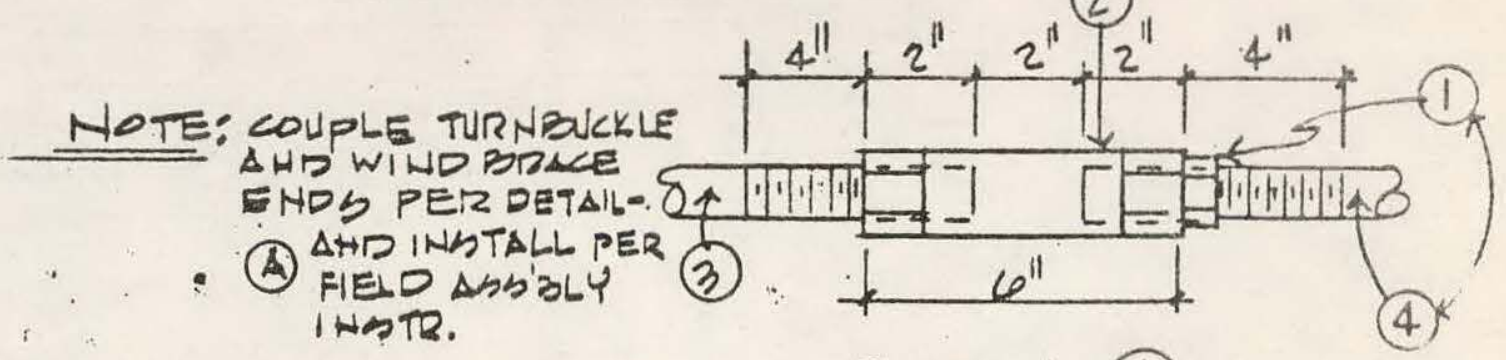

PILL OF MATERIALS

(1) $01-17-011: 31 B^{110}$ HEX. NuT (2)

(2) OI-17-077. 3/8 I:D. $\times 6^{\prime \prime}$ TURNBUUKLE. (2)

(3) 01.17 .098 2l-0l LOWER WIND BRACE. (2)

(4) $01-17-1017-10$ UPPER WIND BRACE.(2)
DETAIL A

F.IELO NSGEMBY I HOTR.

INSERT EACH EHD OF ADSBLY

INTO PROVIDED HLLED. IISE

ONLY THOSE HULES TO THE IHBIDE DF PAL TO JE DRACED.

ADJUE TURNBICKLE TO TICITEN, SNUGLY.

1

REVKED $3 \cdot 2-78$

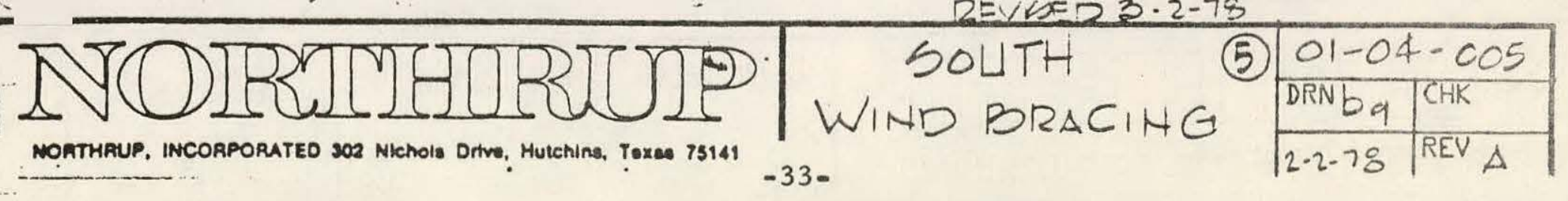



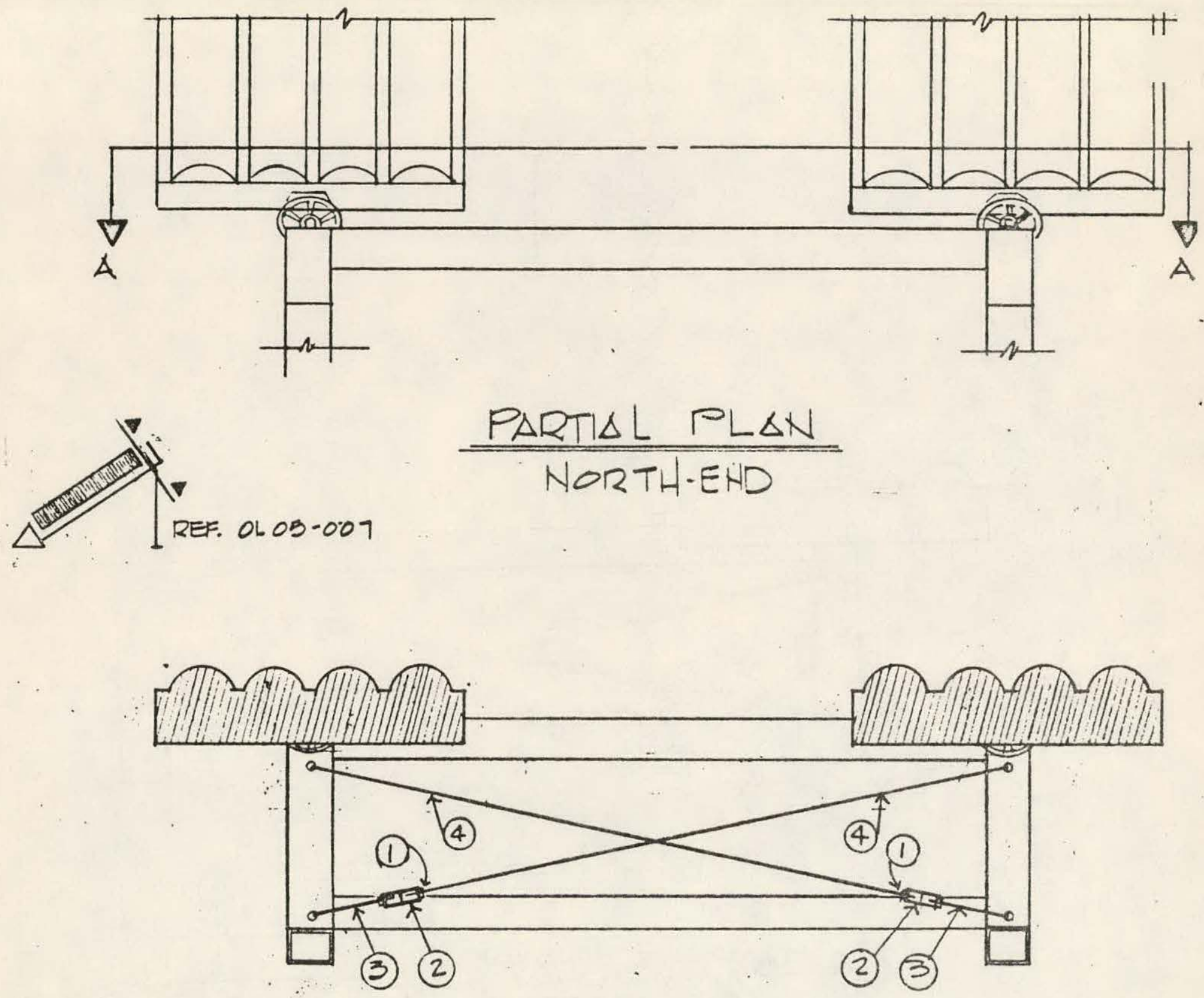

SECTIONA-A

BILL OFMATERISLO:
(1) $01-17-011318^{\prime \prime} \phi$ HEXNUT (2)
(2) $01-17.077$ 3/8.I.P. $\times 6^{\prime \prime}$ TURNBUCKLE.(2)
(3) Ol-17.098 LOWER WIND BRAEE. 2'-"
FIELD LOSEMROLY INBTRULTIOA
(4) $01-17-100$ uPPER WIND Brace. 9-10"
REF. DWC OI-04-005, INSTR. AND DETAIL A.
REVIDED $3-1-78$.

\section{YOIRTMATRIOLP}
OATHAUP, INCORPORATED 302 Nichols Ortvo, Hutehina, Toxes 75148

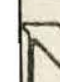
$-$ 


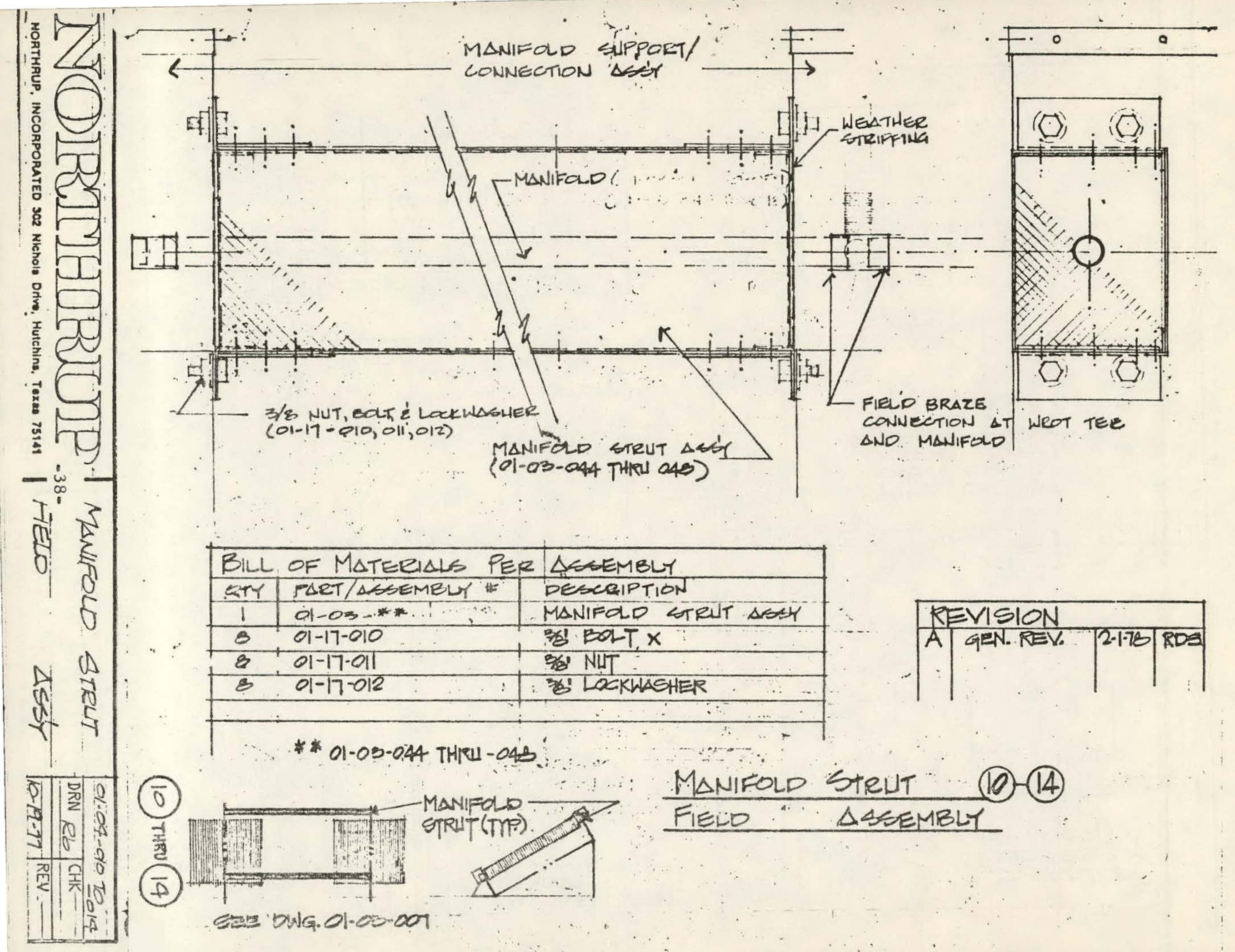



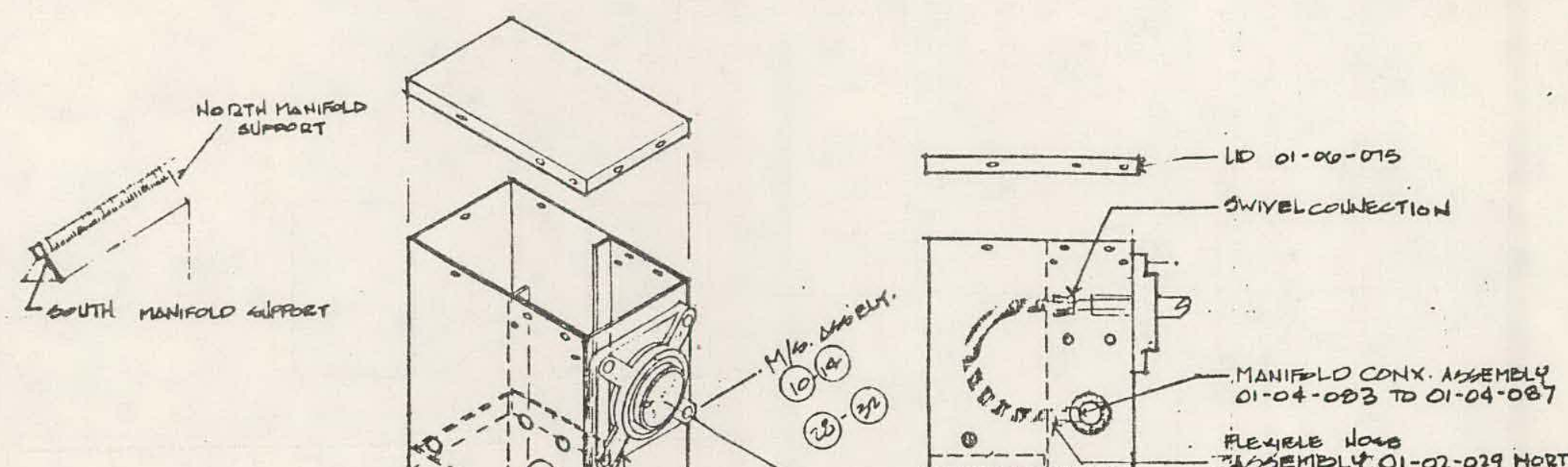

\begin{tabular}{|c|c|c|}
\hline \multicolumn{3}{|c|}{ BILL OF MATERIALS } \\
\hline PTY & PART $N^{*}$ & DESCRIPTION \\
\hline$\left(\begin{array}{c}(\mathrm{Ne} \\
1 \\
1 \\
9\end{array}\right.$ & $\begin{array}{l}\text { RTH) MANIFOLD } \\
01-02-029 \\
01-04-083 T 0877 \\
01-17-008\end{array}$ & 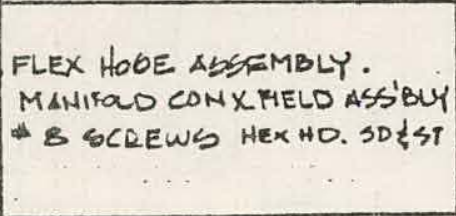 \\
\hline$\left(\begin{array}{c}130 \\
1 \\
1 \\
9\end{array}\right.$ & $\begin{array}{l}\text { TH) MANIFOLD } \\
01-02-030 \\
01-04-083.0087 \\
01-17-008\end{array}$ & 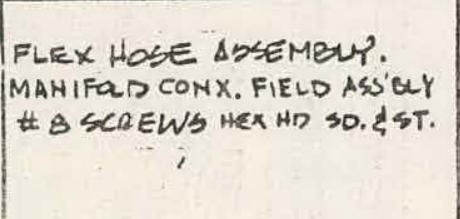 \\
\hline
\end{tabular}

\section{RESEINA To} collector Holes to Elacieve Winto BRAcina
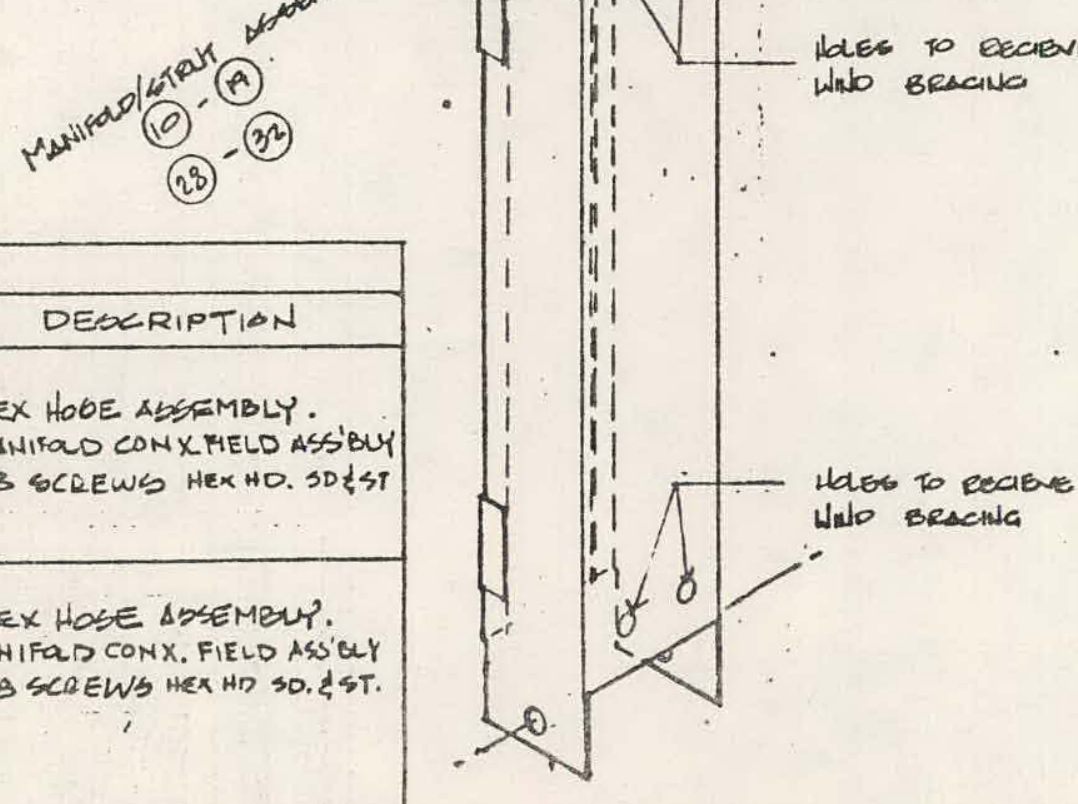

$$
\text { (10) - (14) }
$$



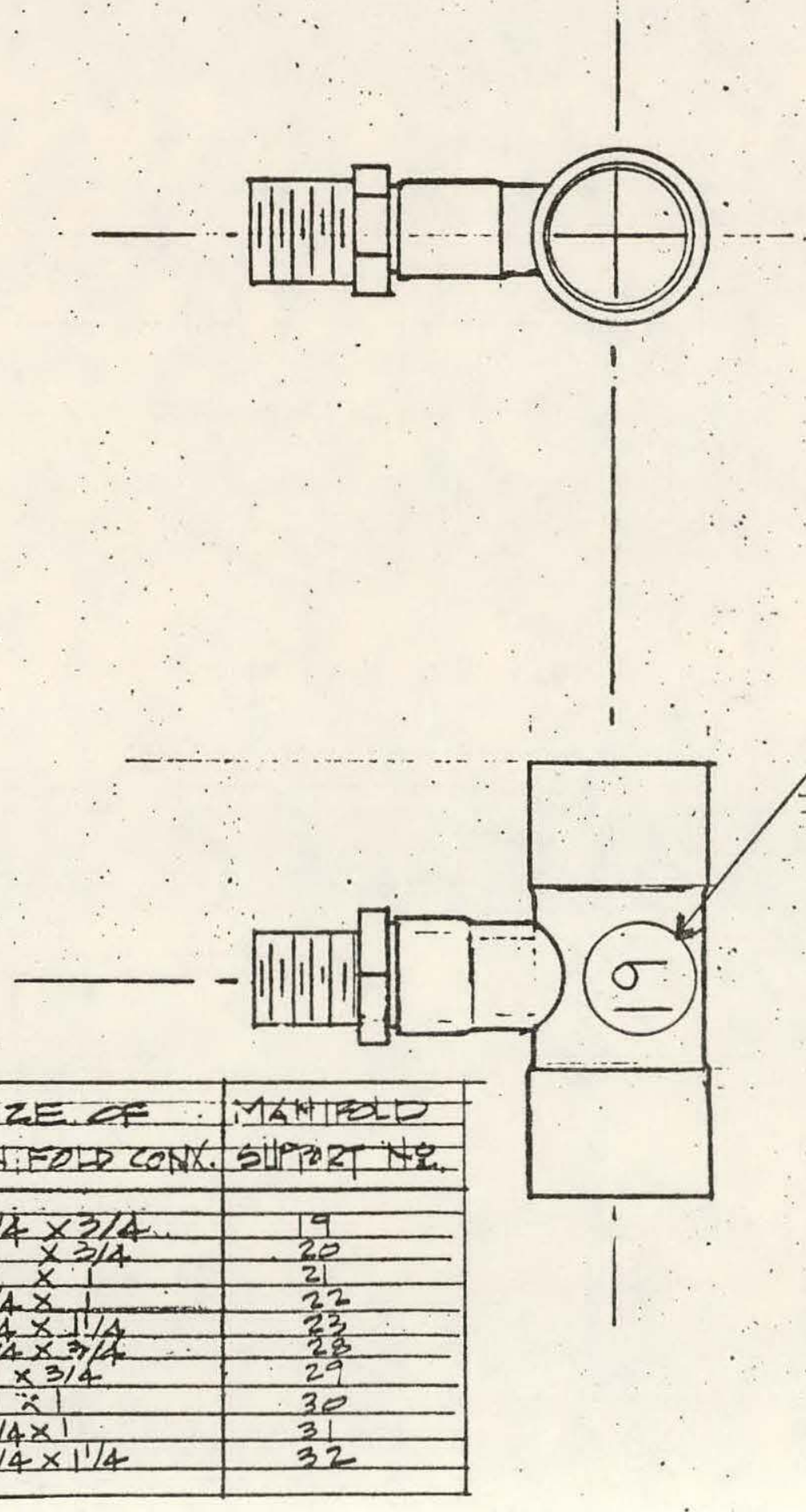

$$
\begin{aligned}
& \text { (10) }-(14) \\
& \text { (28) }-(32) \\
& 01-04-08
\end{aligned}
$$

MANIFAD CONX. FIED throl-0408 $\triangle A B E M B L Y$

\begin{tabular}{|l|l|}
\hline PSN 69 & CPR \\
\hline $5.1-78$ & REV \\
\hline
\end{tabular}




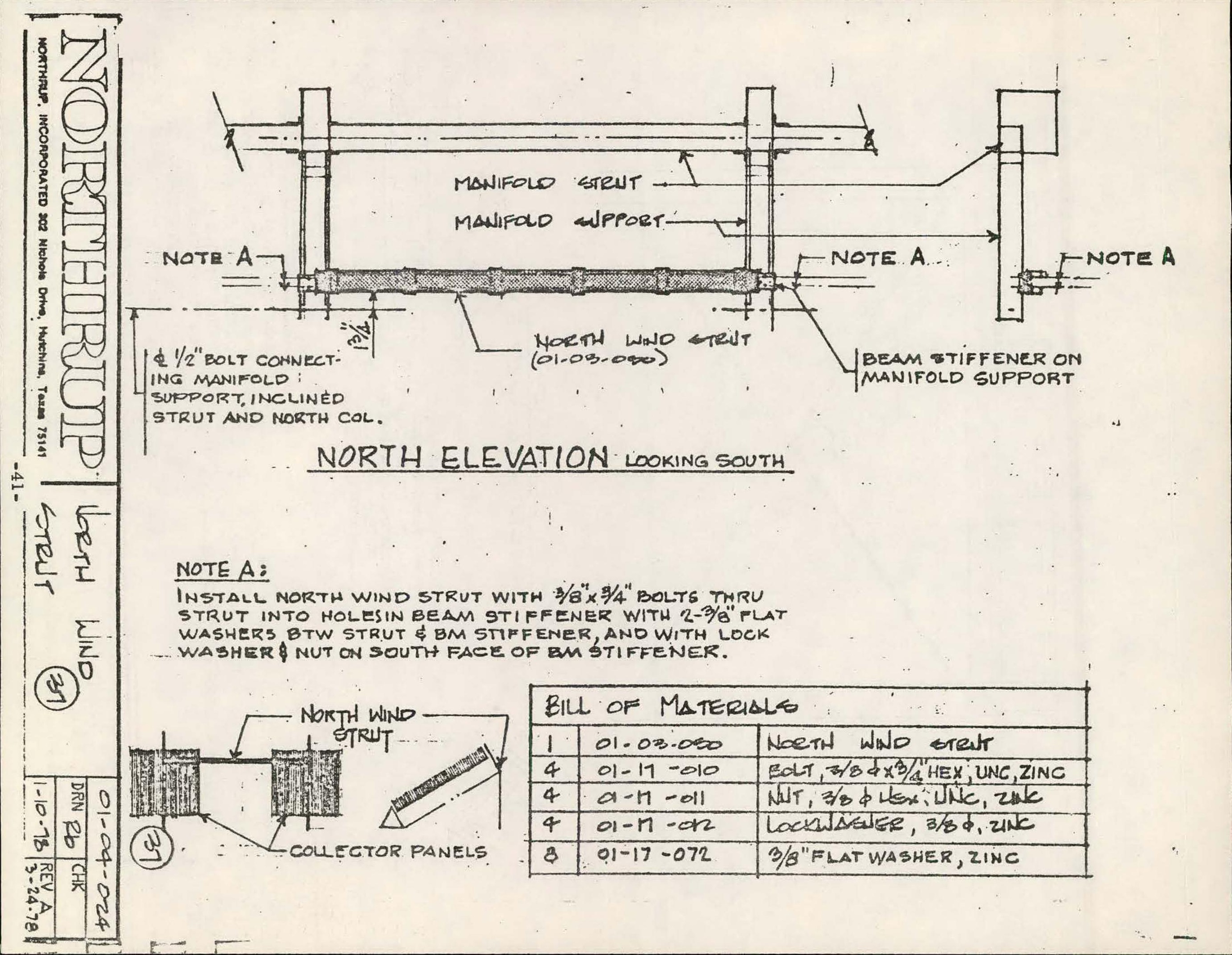




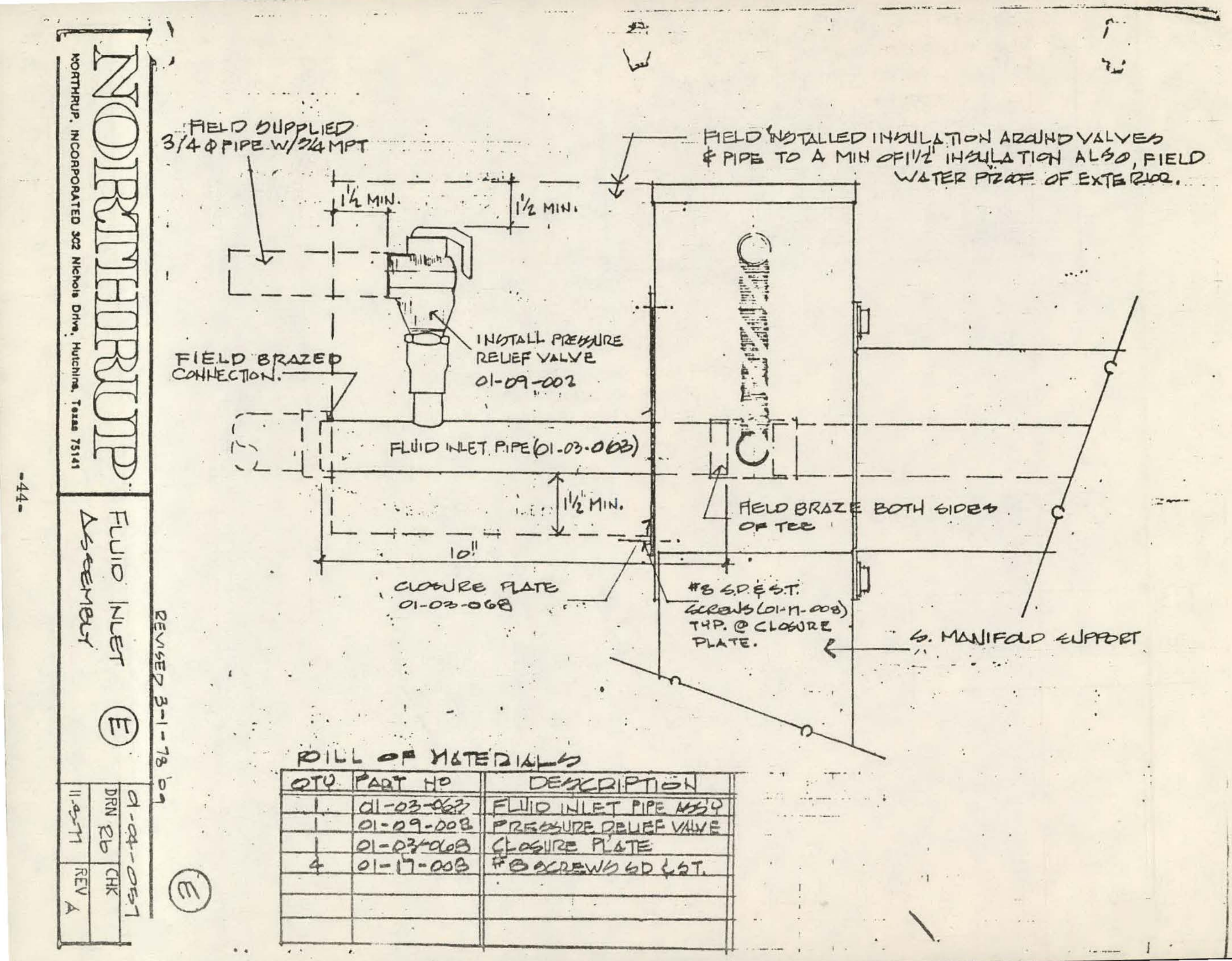




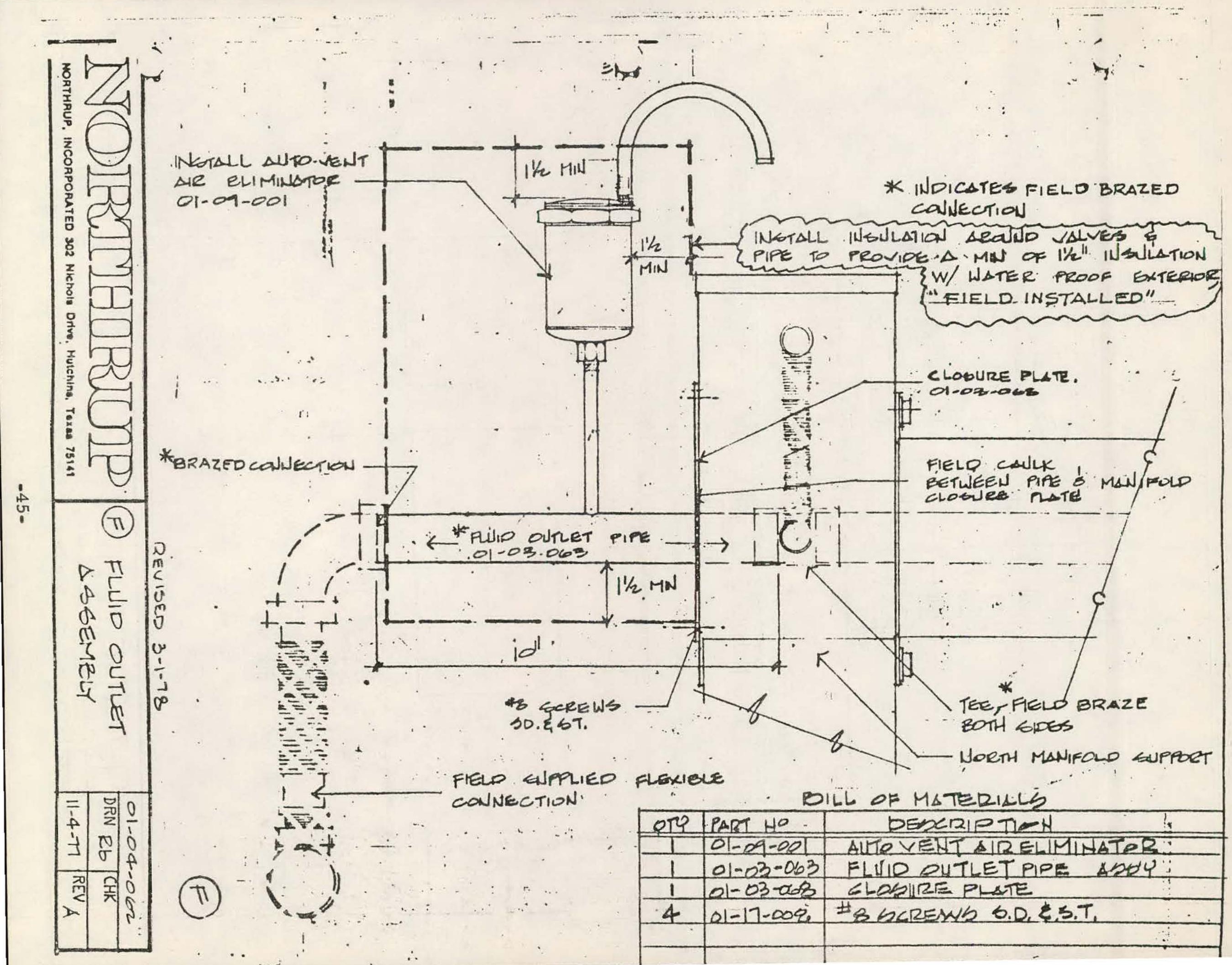




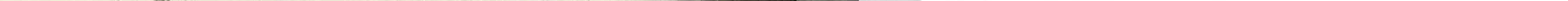




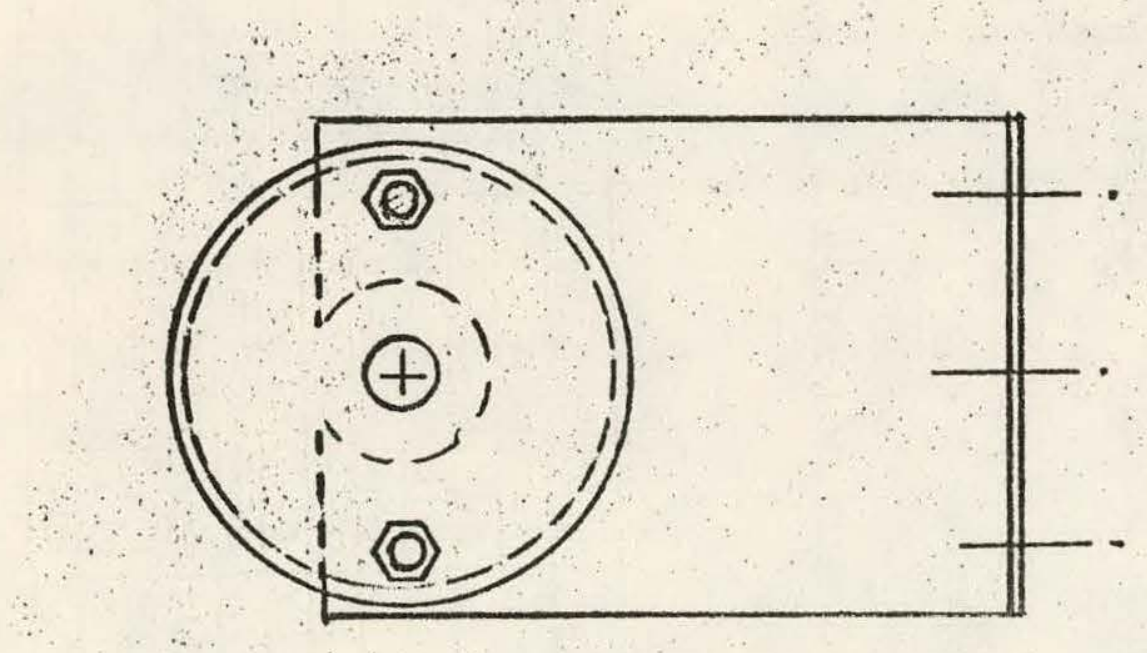

$01-18-004 \quad[01-17-\ldots, 022 \xi 021 \quad 01-06-173$

CARLE GUIDE \$LRHHD SCREW, WASHER CABLE GUIDE DKT. \&L LoK KWABHER.

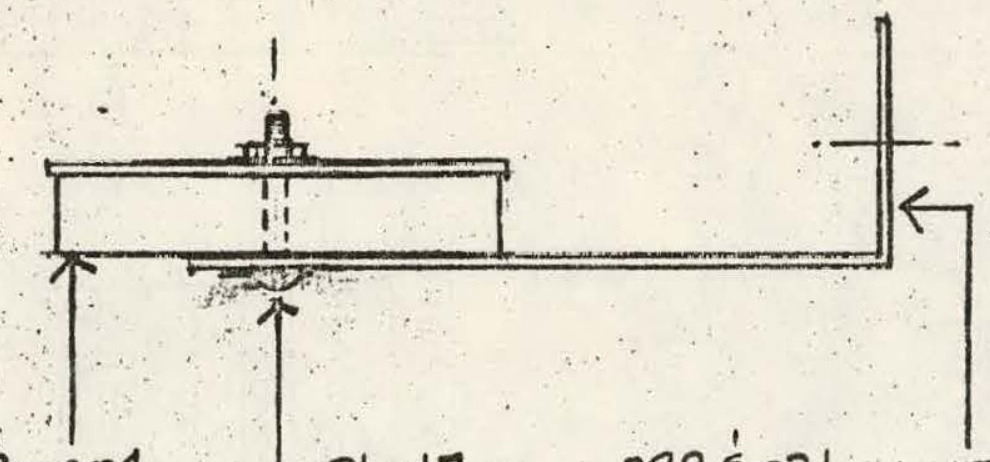




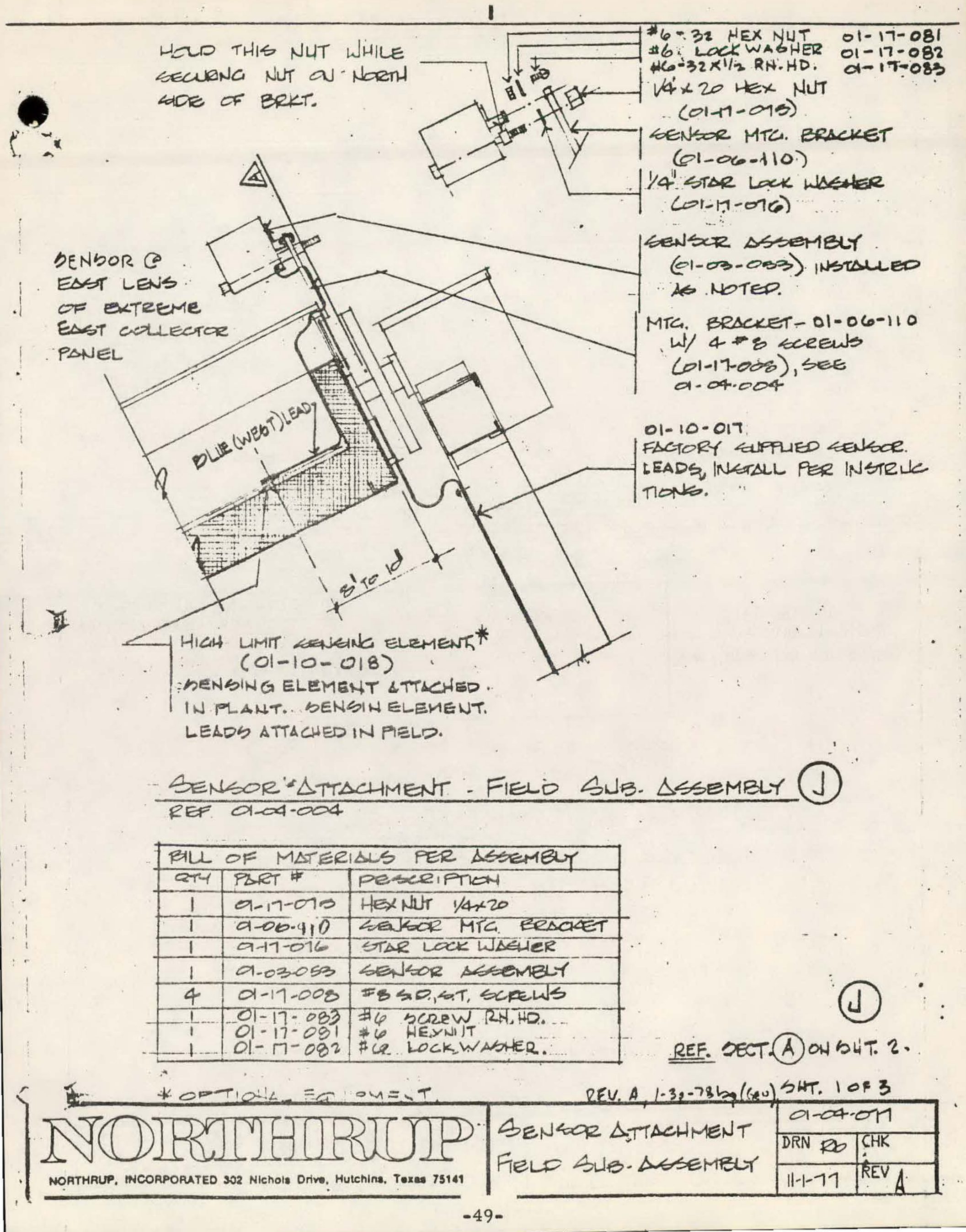


$-1$

E.

-3.06- 104 SENSOR POAITIONING ONT 03.053 SENSUR ASEEMELY

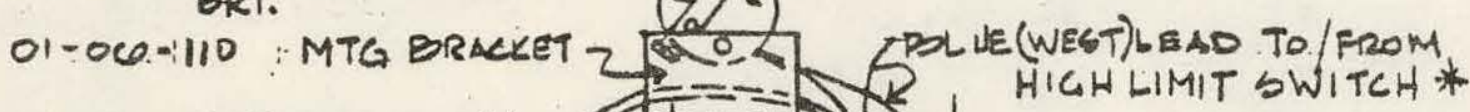

01 $-17-008 N^{0}$ \& screws (4)

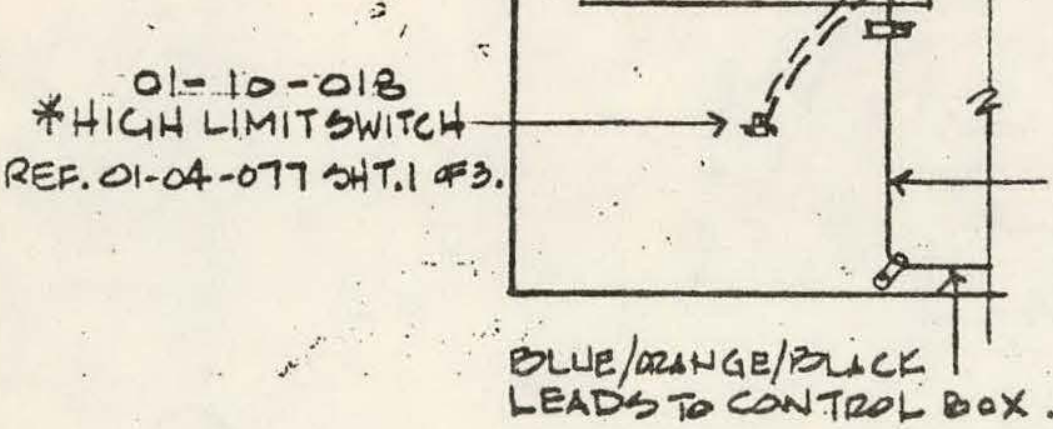

NOTE: ORANGE LEAD - EAST

bLACK LEAO CAMMON

SENSOR ATTACHMENT-FIELD

$\frac{\text { SUB - ASSEMPSLY }}{\text { REF.01.04.004 }}$

HICH LIMIT SWITCH
* OPTIONML EQUIPMENT.

(1)

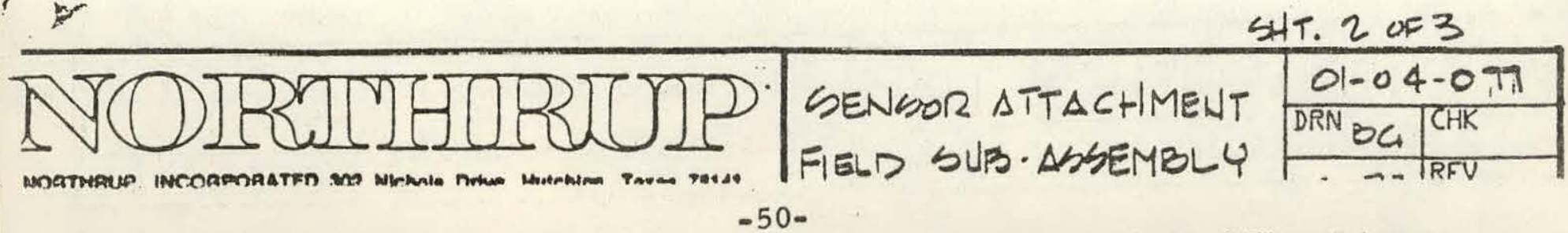

$-50-$ 


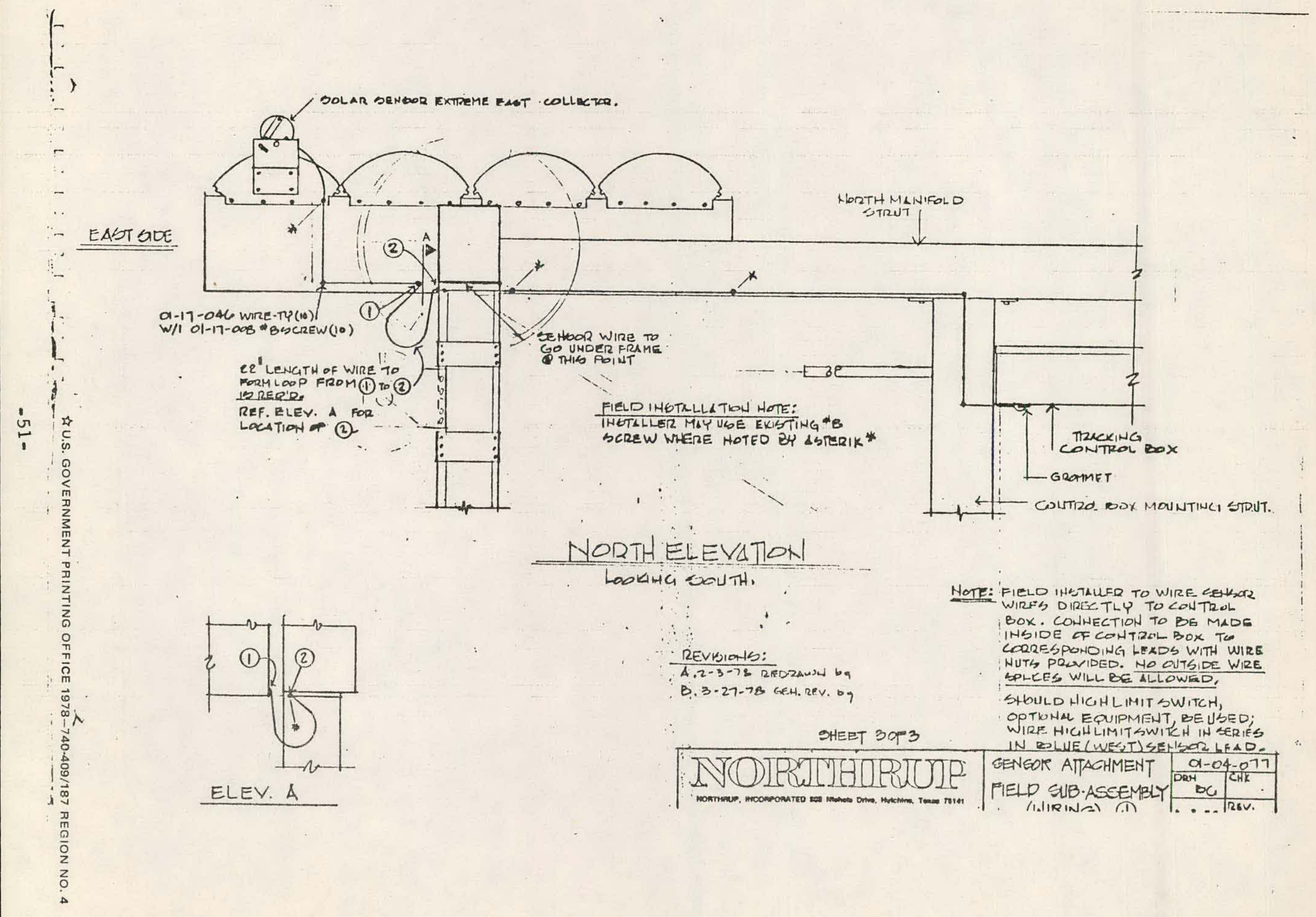

